\title{
DIGITALCOMMONS
}

\section{Right-tailed Testing of Variance for Non-Normal Distributions}

\author{
Michael C. Long \\ Florida State Department of Health \\ Ping Sa \\ University of North Florida, psa@unf.edu
}

Follow this and additional works at: http://digitalcommons.wayne.edu/jmasm

Part of the Applied Statistics Commons, Social and Behavioral Sciences Commons, and the Statistical Theory Commons

\section{Recommended Citation}

Long, Michael C. and Sa, Ping (2005) "Right-tailed Testing of Variance for Non-Normal Distributions," Journal of Modern Applied Statistical Methods: Vol. 4 : Iss. 1 , Article 19.

DOI: $10.22237 /$ jmasm/1114906740

Available at: http://digitalcommons.wayne.edu/jmasm/vol4/iss1/19 


\section{Right-tailed Testing of Variance for Non-Normal Distributions}

\author{
Michael C. Long \\ Florida State Department of Health
}

\author{
Ping Sa \\ Mathematics and Statistics \\ University of North Florida
}

A new test of variance for non-normal distribution with fewer restrictions than the current tests is proposed. Simulation study shows that the new test controls the Type I error rate well, and has power performance comparable to the competitors. In addition, it can be used without restrictions.

Key words: Edgeworth expansion, Type I error rate, power performance

Introduction

Testing the variance is crucial for many real world applications. Frequently, companies are interested in controlling the variation of their products and services because a large variation in a product or service indicates poor quality. Therefore, a desired maximum variance is frequently established for some measurable characteristic of the products of a company.

In the past, most of the research in statistics concentrated on the mean, and the variance has drawn less attention. This article is about testing the hypothesis that the variance is equal to a hypothesized value $\sigma_{o}^{2}$ versus the alternative that the variance is larger than the hypothesized value. This statistical test will be referred to as a right-tailed test in further discussion.

The chi-square test is the most commonly used procedure to test a single variance of a population. Once a random sample of size $n$ is taken, the individual values $X_{i}$, the

Michael C. Long (MA, University of North Florida) is a Research Associate and Statistician in the Department of Health, State of Florida. Email: longstats@cs.com. Ping Sa (Ph. D. University of South Carolina) is a Professor of Mathematics and Statistics at the University of North Florida. Her recent scholarly activities have involved research in multiple comparisons and quality control. Email: psa@unf.edu. sample mean $\bar{X}$, the sample variance $S^{2}$, and specified $\left(\sigma_{o}^{2}\right)$ are used to compute the chisquared test statistic $\chi^{2}=(n-1) S^{2} / \sigma_{0}^{2}$, which is distributed $\chi_{(n-1)}^{2}$ under $H_{0}$. The $\chi^{2}$ statistic is used for hypothesis tests concerning $\sigma^{2}$ when a normal population is assumed. It is well known that the chi-square test statistic is not robust against departures from normality such as when skewness and kurtosis are present. This can lead to rejecting $H_{0}$ much more frequently than indicated by the nominal alpha level, where alpha is the probability of rejecting $H_{0}$ when $H_{0}$ is true.

Practical alternatives to the $\chi^{2}$ test are needed for testing the variance of non-normal distributions. There are nonparametric methods such as bootstrap and jackknife (see Efron \& Tibshirani, 1993). The bootstrap requires extensive computer calculations and some programming ability by the practitioner making the method infeasible for some people. Although the jackknife method is easier to implement, it is a linear approximation to the bootstrap method and can give poor results when the statistic estimate is nonlinear.

Another alternative is presented in Kendall (1994) and Lee and Sa (1998). The robust chi-square statistic $\chi_{r}^{2}$ which has the form $(n-1) \hat{d} S^{2} / \sigma^{2}$ and is chi-square distributed with $(n-1) \hat{d}$ degrees of freedom, 
where $\hat{d}=\left(1+\frac{\hat{\eta}}{2}\right)^{-1}$ and $\hat{\eta}$ is the sample kurtosis coefficient. The critical value for test rejection is $\chi_{v, \alpha}^{2}$ where $v$ is the smallest integer, which is greater than or equal to (n1) $\hat{d}$. Because $\hat{d}$ is a function of the sample kurtosis coefficient $\hat{\eta}$ alone, this could create performance problems for $\chi_{r}^{2}$ test with skewed distributions.

Lee and Sa (1996) derived a new method for a right-tailed variance test of symmetric heavy-tailed distributions using an Edgeworth expansion (see Bickel \& Doksum, 1977), and an inversion type of Edgeworth expansion provided by Hall (1983),

$$
\begin{gathered}
P\left((\hat{\theta}-\theta) / \sigma(\hat{\theta}) \leq x+\beta_{1}\left(x^{2}-1\right) / 6\right) \\
=\Phi(x)+o(1 / \sqrt{n}),
\end{gathered}
$$

where $\hat{\theta}$ is any statistic, and $\theta, \sigma(\hat{\theta})$ and $\beta_{1}$ are the mean, standard deviation and coefficient of skewness of $\hat{\theta}$, respectively. $\Phi(x)$ is the standard normal distribution function.

They considered the variable $S^{2} / \sigma^{2}$, and the variable admitted the inversion of the Edgeworth expansion above as follows:

$$
\begin{gathered}
P\left(\frac{\frac{S^{2}}{\sigma^{2}}-1}{\sqrt{\frac{K_{4}}{n \sigma^{4}}+\frac{2}{n-1}}} \leq x+\beta_{1}\left(x^{2}-1\right) / 6\right. \\
=\Phi(x)+o(1 / \sqrt{n})
\end{gathered}
$$

where $K_{4}=E(X-\mu)^{4}-3\left(E(X-\mu)^{2}\right)^{2}$ and $\beta_{1}=\frac{E\left(S^{2}-\sigma^{2}\right)^{3}}{\left(E\left(S^{2}-\sigma^{2}\right)^{2}\right)^{3 / 2}}$, the coefficient of skewness of $S^{2}$, provided all the referred moments exist. The population coefficient of skewness equals $K_{3} / \sqrt{\left(\sigma^{2}\right)^{3}}=0$ under symmetric and heavy-tailed assumptions, and the population coefficient of kurtosis equals $K_{4} / \sigma^{4}>0$, where $K_{i}$ is the $i^{\text {th }}$ cumulant (see
Kendall \& Stuart, 1969). This yielded a decision rule:

Reject $H_{0}: \sigma^{2}=\sigma_{0}^{2}$ versus $H_{a}: \sigma^{2}>\sigma_{0}^{2}$ if $Z>z_{\alpha}+\hat{\beta}_{1}\left(z_{\alpha}^{2}-1\right) / 6$,

where $z_{\alpha}$ is the upper $\alpha$ percentage point of the standard normal distribution,

$$
\begin{gathered}
Z=\frac{\frac{S^{2}}{\sigma_{0}^{2}}-1}{\sqrt{\frac{k_{4}}{n \sigma_{0}}+\frac{2}{n-1}}}, \text { and } \\
\hat{\beta}_{1}=\frac{\frac{1}{n^{2}}\left[\frac{3 n}{2} k_{4} S^{2}-\frac{1}{2} k_{6}+\frac{8 n^{2}}{(n-1)^{2}}\left(S^{2}\right)^{3}\right]}{\sqrt{\left(\frac{k_{4}}{n}+\frac{2\left(S^{2}\right)^{2}}{n-1}\right)^{3}}},
\end{gathered}
$$

where $k_{i}$ is the $i^{t h}$ sample cumulant.

They approximated their decision rule even further using a Taylor series expansion of $f^{-1}(Z)$ at $-a$ where $a=\hat{\beta}_{1} / 6$. The new test became:

Reject $H_{0}$ if

$$
Z_{1}=Z-a\left(Z^{2}-1\right)+2 a^{2}\left(Z^{3}-Z\right)>z_{\alpha} \text {. }
$$

After a simulation study, their study found their test provided a "controlled Type I error rate as well as good power performance when sample size is moderate or large" (p. 51).

Lee and Sa (1998) performed another study on a right-tailed test of variance for skewed distributions. A method similar to the previously proposed study was employed with the primary difference being in the estimated coefficient of skewness, $\hat{\beta}_{1}$. The population coefficient of skewness, $K_{3} / \sqrt{\left(\sigma^{2}\right)^{3}}$, was assumed zero in the heavy-tailed distribution study and estimated for the skewed distribution study. Their study performed a preliminary 
simulation study for the best form of $Z$ and found

$$
Z=\frac{\frac{S^{2}}{\sigma_{0}^{2}}-1}{\sqrt{\frac{k_{4}}{n S^{2} \sigma_{0}^{2}}+\frac{2}{n-1}}}
$$

to be the $Z$ with controllable Type I error rates as well as good power performance.

Hence, the motivation for this study is to develop an improved method for right-tailed tests of variance for non-normal distributions. A test is desired which works for both skewed and heavy-tailed distributions and also has fewer restrictions from assumptions. This test should work well for multiple sample sizes and significance levels. The test proposed uses a general Edgeworth expansion to adjust for the non-normality of the distribution and considers the variable $S^{2}$ that admits an inversion of the general Edgeworth expansion.

A detailed explanation of the new method is provided in the next section. In the "Simulation Study" Section, the simulation study is introduced for determining whether the previously proposed tests or the new test has the best true level of significance or power. The results of the simulation are discussed in the section of Simulation Results. Conclusions of the study are rendered at the end.

\section{Methodology}

Let $\hat{\theta}$ be an estimate of an unknown quantity $\theta_{o}$. If $\sqrt{n}\left(\hat{\theta}-\theta_{o}\right)$ is asymptotically normally distributed with zero mean and variance $\sigma^{2}$, the distribution function of $\sqrt{n}\left(\hat{\theta}-\theta_{o}\right)$ may be expanded as a power series in $\sqrt{n}$ (see Hall, 1983),

$$
\begin{aligned}
& P\left\{\frac{\sqrt{n}\left(\hat{\theta}-\theta_{o}\right)}{\sigma} \leq x\right\}= \\
& \Phi(x)+n^{-\frac{1}{2}} p_{1}(x) \phi(x)+\cdots+n^{-\frac{j}{2}} p_{j}(x) \phi(x)+\cdots,
\end{aligned}
$$

where $\phi(x)=(2 \pi)^{-1 / 2} e^{-\frac{x^{2}}{2}}$ is the Standard Normal density function and $\Phi(x)=\int_{-\infty}^{x} \phi(u) d u$ is the Standard Normal distribution function. The functions $p_{j}$ are polynomials with coefficients depending on cumulants of $\hat{\theta}-\theta_{o}$.

From Hall (1992), the Edgeworth expansion for the sample variance is

$$
\begin{aligned}
& P\left\{\frac{\sqrt{n}\left(S^{2}-\sigma^{2}\right)}{\tau} \leq x\right\} \\
& =\Phi(x)+n^{-\frac{1}{2}} p_{1}(x) \phi(x)+\cdots+n^{-\frac{j}{2}} p_{j}(x) \phi(x)+\cdots,
\end{aligned}
$$

where

$$
\begin{aligned}
& p_{1}=-\left(B_{1}+B_{2} \frac{x^{2}-1}{6}\right), B_{1}=-\left(v_{4}-1\right)^{-1 / 2}, \\
& B_{2}=\left(v_{4}-1\right)^{-3 / 2}\left(v_{6}-3 v_{4}-6 v_{3}^{2}+2\right), \\
& v_{j}=E\{(X-\mu) / \sigma\}^{j}, \\
& \text { and } \tau=\sqrt{E(X-\mu)^{4}-\sigma^{4}} .
\end{aligned}
$$

The variable $S^{2}$ admits the inversion of the Edgeworth expansion as follows:

$$
\begin{aligned}
& P\left\{\frac{\sqrt{n}\left(S^{2}-\sigma^{2}\right)}{\tau} \leq x+n^{\frac{-1}{2}}\left(B_{1}+B_{2} \frac{x^{2}-1}{6}\right)\right\} . \\
& =\Phi(x)+o\left(n^{-1 / 2}\right)
\end{aligned}
$$

To test $H_{o}: \sigma^{2}=\sigma_{o}^{2} \quad$ versus $H_{a}: \sigma^{2}>\sigma_{o}^{2}$, one can adapt the inversion 
formula of the Edgeworth expansion, and the result is an intuitive decision rule as follows:

Reject $H_{o}$ if $Z>z_{\alpha}+n^{\frac{-1}{2}}\left(\hat{B}_{1}+\hat{B}_{2} \frac{z_{\alpha}^{2}-1}{6}\right)$,

where $z_{\alpha}$ is the upper $\alpha$ percentage point of the standard normal distribution,

$$
\begin{gathered}
\mathrm{Z}=\frac{S^{2}-\sigma_{0}^{2}}{\tau / \sqrt{n}}, \hat{B}_{1}=-\left(\frac{S^{4}}{k_{4}+2 S^{4}}\right)^{1 / 2}, \\
\hat{B}_{2}=-\left(\frac{k_{6}+12 k_{4} S^{2}+4 k_{3}^{2}+8\left(S^{2}\right)^{3}}{\left(k_{4}+2 S^{4}\right)^{3 / 2}}\right) .
\end{gathered}
$$

\section{Simulation Study}

Details for the simulation study are provided in this section. The study is used to compare Type I error rates and the associated power performance of the different right-tail tests for variance.

\section{Distributions Examined}

Distributions were chosen to achieve a range of skewness (0.58 to 9.49) or kurtosis $(-1.00$ to 75.1$)$ for comparing the test procedures. The skewed distributions considered in the study included Weibull with scale parameter $\lambda=1.0$ and shape parameters $=0.5$, $0.8, \quad 2.0 \quad$ (see Kendall, 1994), Lognormal $(\mu=0, \sigma=1)$, (see Evans, Hastings, $\&$ Peacock, 2000), Gamma with scale parameter 1.0 and shape parameters $=0.15,1.2,4.0$ (see Evans, Hastings, \& Peacock, 2000), 10 Inverse Guassian distributions with $\mu=1.0$, scale parameters $\lambda=0.1$ to 25.0 with skewness ranging from 0.6 to 9.49 (see Chhikara \& Folks, 1989 and Evans, Hastings, \& Peacock, 2000), Exponential with $\mu=1.0$ and $\lambda=1.0$ (see Evans, Hastings, \& Peacock, 2000), Chi-square with $v$ degrees of freedom $(v=1,2,3,4,8,12$, $16,24)$, and a polynomial function of the standard normal distribution Barnes2 (see Fleishman 1978).
The heavy-tailed distributions considered included Student's T ( $v=5,6,8,16,32,40), 10 \mathrm{JTB}(\alpha, \tau)$ distributions with $(\mu=0, \sigma=1)$ and various $\alpha, \tau$ values including Laplace $\alpha=2.0, \tau=1.0$ ), (see Johnson, Tietjen, \& Beckman, 1980), and special designed distributions which are polynomial functions of the standard normal distribution: Barnes1 and Barnes3 having kurtosis 6.0 and 75.1 respectively (see Fleishman 1978). All the heavy-tailed distributions are symmetric with the exception of Barnes3. Barnes3 has skewness of .374 which is negligible in comparison to the kurtosis of 75.1. Therefore, Barnes3 was considered very close to symmetric.

\section{Simulation Description}

Simulations were run using Fortran 90 for Windows on an emachines etower 400i PC computer. All the Type I error and power comparisons for the test procedures used a simulation size of 100,000 in order to reduce experimental noise. Fortran 90 IMSL library was used to generate random numbers from these distributions: Weibull, Lognormal, Gamma, Exponential, Chi-square, Normal and Student's T. In addition, the Inverse Gaussian, JTB, Barnes1, Barnes2, and Barnes3 random variates were created with Fortran 90 program subroutines using the IMSL library's random number generator for normal, gamma, and uniform in various parts of the program.

The following tests were compared in the simulation study:

1) $\chi^{2}=(n-1) S^{2} / \sigma_{0}^{2}$; the decision rule is Reject $H_{0}$ if $\chi^{2}>\chi_{n-1, \alpha}^{2}$.

2) $\chi_{r}^{2}=(n-1) \hat{d} S^{2} / \sigma_{0}^{2}$; the decision rule is Reject $H_{0}$ if $\chi_{r}^{2}>\chi_{v, \alpha}^{2}$, where $v$ is the smallest integer that is greater than or equal to (n-1) $\hat{d}$. 
3) $\mathrm{Zs}=\frac{\frac{S^{2}}{\sigma_{0}^{2}}-1}{\sqrt{\frac{k_{4}}{n S^{2} \sigma_{0}^{2}}+\frac{2}{n-1}}}$ from Lee and $\mathrm{Sa}$

(1998); the decision rule is Reject $H_{0}$ if $Z s-a\left(Z s^{2}-1\right)+2 a^{2}\left(Z s^{3}-Z s\right)>z_{\alpha}$.

4) $\mathrm{Zh}=\frac{\frac{S^{2}}{\sigma_{0}^{2}}-1}{\sqrt{\frac{k_{4}}{n \sigma_{0}^{4}}+\frac{2}{n-1}}}$ from Lee and $\mathrm{Sa}$

(1996); the decision rule is Reject $H_{0}$ if $Z h-a\left(Z h^{2}-1\right)+2 a^{2}\left(Z h^{3}-Z h\right)>z_{\alpha}$.

5) The proposed test is $Z=\frac{S^{2}-\sigma_{0}^{2}}{\tau / \sqrt{n}}$, where $\tau / \sqrt{n}$ can be estimated by different forms to create different test statistics; the decision rule is

$$
\begin{array}{ccc}
\text { Reject } & H_{0} \quad \text { if } \\
z_{\alpha}+n^{\frac{-1}{2}}\left(\hat{B}_{1}+\hat{B}_{2} \frac{z_{\alpha}^{2}-1}{6}\right)
\end{array}
$$

Six different test statistics were investigated:

$$
\begin{aligned}
& \mathrm{Zn}=\frac{S^{2}-\sigma_{0}^{2}}{\sqrt{\frac{k_{4}}{n}+\frac{2 S^{2} \sigma_{0}^{2}}{n-1}}}, \\
& \mathrm{Z} 2=\frac{S^{2}-\sigma_{0}^{2}}{\sqrt{\frac{k_{4}}{n}+\frac{2 \sigma_{0}^{4}}{n-1}}}, \\
& \mathrm{Z} 3=\frac{S^{2}-\sigma_{0}^{2}}{\sqrt{\frac{k_{4}}{n}+\frac{2 S^{4}}{n-1}}},
\end{aligned}
$$

$$
\begin{aligned}
& \mathrm{Z} 4=\frac{S^{2}-\sigma_{0}^{2}}{\sqrt{\frac{(n-1) k_{4}}{n(n+1)}+\frac{2 S^{4}}{n+1}}}, \\
& \mathrm{Z} 5=\frac{S^{2}-\sigma_{0}^{2}}{\sqrt{\frac{k_{4} \sigma_{0}^{4}}{n S^{4}}+\frac{2 \sigma_{0}^{4}}{n-1}}}, \\
& \text { and } \mathrm{Z} 6=\frac{S^{2}-\sigma_{0}^{2}}{\sqrt{\frac{k_{4} \sigma_{0}^{2}}{n S^{2}}+\frac{2 \sigma_{0}^{4}}{n-1}}} .
\end{aligned}
$$

The equation $\frac{(n-1) k_{4}}{n(n+1)}+\frac{2 S^{4}}{n+1}$ in $\mathrm{Z} 4$ is the unbiased estimator for $V\left(S^{2}\right)=\tau^{2} / n$. Sample sizes of 20 and 40 were investigated for Type I error rates along with the nominal alpha levels $0.01,0.02,0.05$, and 0.10 for each sample size. Furthermore, any test that used $z_{\alpha}$ also used $\left(z_{\alpha}+t_{n-1, \alpha}\right) / 2$ and $t_{n-1, \alpha}$ separately with each sample size and nominal level for further flexibility in determining the best test. For each sample size and nominal level, 100,000 simulations were generated from each distribution. All the tests investigated were applied to each sample. The proportion of samples rejected from the 100,000 was then recorded based on the sample size, nominal level, and test procedure.

The steps for conducting the simulation were as follows:

1. Generate a sample of size $n$ from one parent distribution under $H_{0}$.

2. Calculate: $\bar{X}, S^{2}, k_{3}, k_{4}, k_{6}, \hat{\beta}_{1}, \hat{B}_{1}, \hat{B}_{2}$.

3. Calculate all the test statistics: $\chi^{2}, \chi_{r}^{2}, Z s$, Zh, Zn, Z2, Z3, Z4, Z5, and Z6.

4. Find the critical value for each test considered. 
5. Determine for each test whether rejection is warranted for the current sample and if so, increment the respective counter.

6. Repeat 1 through 5 for the remaining 99,999 samples.

\section{Calculate the proportion of 100,000 rejected.}

A power study was performed using five skewed distributions and five heavy-tailed distributions with varying degrees of skewness and kurtosis respectively. For each distribution considered, sample sizes of 20 and 40 were examined with nominal levels of 0.10 and 0.01 , and $k=1,2,3,4,5,6$, where $k$ is a constant such that the $\sqrt{k}$ is multiplied to each variate.

The traditional power studies were performed by multiplying the distribution observations by $\sqrt{k}$ to create a new set of observations yielding a variance $k$ times larger than the $H_{0}$ value. Steps 1 through 6 above would then be implemented for the desired values of $k$, sample sizes, and significance levels. The power would then be the proportion of 100,000 rejected for the referenced value of $k$, sample size, and significance level.

This method has been criticized by many researchers since tests with high Type I error rates frequently have high power also. Tests with high Type I error rates usually have fixed lower critical points relative to other tests and therefore reject more easily when the true variance is increased. Hence, these tests tend to have higher power.

Some researchers are using a method to correct this problem. With $k=1$, the critical point for each test under investigation is adjusted till the proportion rejected out of 100,000 is the same as the desired nominal level. The concept is that the tests can be compared better for power afterward since all the tests have critical points adjusted to approximately the same Type I error rate. Once this is accomplished, steps 1 through 7 above are performed for each $k$ under consideration to get a better power comparison between the different tests at that level of $k$.
The traditional power study and the new power study were used to provide a complete picture of the power performance by each test.

\section{Results}

\section{Type I Error Comparison}

Comparisons of Type I error rates for skewed and heavy-tailed distributions were made for sample size 40 and 20 with levels of significance $0.10,0.05,0.02$, and 0.01 . However, the results are very similar between the two higher levels of significance $(0.10$ and 0.05 ) and the same situation holds for the two lower levels of significance. Therefore, only 0.05 and 0.01 levels are reported here and they are summarized into Tables 1 through 4 . Also, it can be observed that the Type I error performances are quite similar for the skewed distributions with similar coefficient of skewness or for the heavy-tailed distributions with similar coefficient of kurtosis. Therefore, only 11 out of the original 27 skewed distributions and 10 out of the 18 heavy-tailed distributions studied are reported in these tables. For the complete simulation results, please see Long and Sa (2003).

Comparisons were made between the tests $\chi^{2}, \chi_{r}^{2}$ (first and second number in the first column), and $\mathrm{Zs}, \mathrm{Zh}, \mathrm{Z} 2$, and Z6 with $z_{\alpha}$, $\left(z_{\alpha}+t_{n-1, \alpha}\right) / 2$, and $t_{n-1, \alpha}$ as the first, second, and third number in the respective column. The tests Zn, Z3, Z4, and Z5 were left out of the table since they were either unstable over different distributions or had highly inflated Type I error rates. From Tables 1 through 4, the following points can be observed:

The traditional $\chi^{2}$ test is more inflated than the other tests for all the distributions, sample sizes and significance levels.

The $\chi_{r}^{2}$ test does not maintain the Type I error rates well for the skewed distribution cases. The Type I error rates can be more than $300 \%$ inflated than the desired level of significance in some of the distributions. This is especially true for the distributions with a higher coefficient of skewness. However, the $\chi_{r}^{2}$ test performs much better in the heavy-tailed 
distributions. Although there are still some inflated cases, they are not severe. These results are understandable since the $\chi_{r}^{2}$ test only adjusts for the kurtosis of the sampled distribution and not the skewness.

The Z2 test's Type I error rates reported in Tables 1 and 2 were extremely conservative for most of the skewed distributions. It becomes even more conservative when the coefficient of skewness gets larger. In fact, the $\mathrm{Z} 2$ test is so conservative it is rarely inflated for any of the skewed or heavy-tailed distribution cases.

Similar to the $\mathrm{Z} 2$ test, test $\mathrm{Zh}$ performs quite conservatively in all the skewed distributions as well. However, it performs differently under heavy-tailed distributions. The Type I error rates become closer to the nominal level except for one distribution, and there are even a few inflated cases. The exception in the heavy-tailed distributions is the Barnes3. In this case, test $\mathrm{Zh}$ is extremely conservative for all the nominal levels.

Under the skewed distribution, the Zs test performs well for the sample size 40 and the nominal level 0.05 . However, the Type I error rates become more or less uncontrollable when either the alpha level gets small or the sample size is reduced. These results confirmed the recommendations of Lee and $\mathrm{Sa}$ (1998) that $\mathrm{Zs}$ is more suitable for moderate to large sample sizes and alpha levels not too small. Although Zs was specifically designed for the skewed distributions, it actually works reasonably well for the heavy-tailed distributions as long as the sample size and/or the alpha level are not too small.

Generally speaking, the proposed test Z6 controls Type I error rates the best in both the skewed distribution cases and the heavytailed distribution cases. Only under some skewed distributions with both small alpha and small sample size were there a few inflated Type I error rates. However, the rates of inflation are at much more acceptable level than some others.

\section{Power Comparison Results}

One of the objectives of the study is to find one test for non-normal distributions with an improved Type I error rate and power over earlier tests. It was suspected that tests with very conservative Type I error rates might have lower power than other tests since it is harder to reject with these tests. Because tests $\mathrm{Zh}$ and $\mathrm{Z} 2$ were extremely conservative for the skewed distributions, exploratory power simulations were run on a couple of mildly skewed distributions with $\mathrm{Zs}, \mathrm{Zh}, \mathrm{Z} 2$, and $\mathrm{Z6}$ to further decrease the potential tests. The preliminary power comparisons confirmed our suspicion. Both $\mathrm{Zh}$ and $\mathrm{Z} 2$ have extremely low power even when $k$ is as large as 6.0. Therefore, Z2 will not be looked at further since $\mathrm{Z6}$ is the better performer of the new tests. Also, the Zh test's power is unacceptable, but it will still be compared for the heavy-tailed distributions since that is what it was originally designed for. The results of the preliminary power study are reported in Long and Sa (2003).

Tables 5 and 6 provide the partial results from the new type of power comparisons, and Tables 7 and 8 consist of some results from the traditional type of power study. Based on the complete power study in Long and Sa (2003), the following expected similarities can be found for the power performance of the tests between the skewed and heavy-tailed distributions regardless of the type of power study. When the sample size decreases from 40 to 20 , the power decreases. As the $k$ in $k \cdot \sigma_{0}^{2}$ increases, the power increases. When the significance level decreases from 0.10 to 0.01 , the power decreases more than the decrease experienced with the sample size decrease. As the skewness of the skewed distribution decreases, the power increases. As the kurtosis of the heavy-tailed distribution decreases, the power increases overall with a slight decrease from the $T(5)$ distribution to the Laplace distribution.

The primary difference overall between the skewed and heavy-tailed distributions is that the power is better for the heavy-tailed distributions when comparing the same sample size, significance level, and $k$. In fact, the power increases more quickly over the levels of $k$ for the heavy-tailed distributions versus the skewed distributions, with a more noticeable difference at the higher levels of kurtosis and skewness respectively.

Some specific observations are summarized as follows: 
It can be observed that the $\chi^{2}$ test performed worst overall with its power lower than the other tests' power based on the new power study. There are several cases where the $\chi^{2}$ test's power is lower than the other tests' powers by $10 \%$ or more. As can be expected, the $\chi^{2}$ test has very good power performance under the traditional power study, which provides the true rejection power under the specific alternative hypothesis. However, since the test had uncontrollable and unstable Type I error rates, this test should not be used with confidence.

The $\chi_{r}^{2}$ test has a better power performance than the $\chi^{2}$ test in the new power study, and it performs as well as the $\chi^{2}$ test in the traditional power study. But similar to the $\chi^{2}$, the test is not recommended due to the unstable Type I error rates.

Differences between the power performances of the Z6 and Zs tests are very minor, and they are slightly better than the $\chi_{r}^{2}$ test in the new power study. More than $50 \%$ of the cases studied have differences in power within $2 \%$ between any two tests. In the traditional power study, the Z6 and Zs tests are not as powerful as either the $\chi^{2}$ test or the $\chi_{r}^{2}$ test for the skewed distributions studied. However, they perform quite well also. On the heavy-tailed distributions studied, the $\mathrm{Z6}$ and $\mathrm{Zs}$ tests have very good power performance which is constantly as high as the power of the $\chi_{r}^{2}$ test, and sometimes almost as high as the power of the $\chi^{2}$ test. To further differentiate the two in the traditional power study, the Z6 test performed better than Zs when $\alpha=0.10$ and worse when $\alpha=0.01$.

The $\mathrm{Zh}$ test is studied only for the heavy-tailed distributions. With the adjusted critical values on the new power study, Zh has the most power among the five tests. However, as far as the true rejection power is concerned, it has the lowest power in almost all of the cases studied.

\section{More Comparisons of Type I Error Rates Between Zs and Z6}

After reviewing the results from the Type I error rate comparison study and the power study, the tests Zs and Z6 are the best. Therefore, the two tests were examined for a Type I error rate comparison study of sample size 30. Looking at the skewed distributions and heavy-tailed distributions in Table 9 , both tests held the Type I error rates well at $\alpha=0.10$ and $\alpha$ $=0.05$. For the skewed distributions, the Zs test's Type I error rates were much more inflated overall for the lower alpha levels of 0.02 and 0.01. In fact, the number of inflated cases for $\mathrm{Zs}$ compared to Z6 was more than double. Breadth of the inflation was also larger with the Zs test having $22 \%$ of the cases greater than a $50 \%$ inflation rate (i.e. $50 \%$ higher than the desired nominal level), while the Z6 test had none. Similar results can be observed for the heavytailed distributions as well. Clearly, the Z6 test controls Type I error rates better than the Zs test for sample sizes of 30 also.

Although most of the Type I error rates for the Z6 test are stable, there was some inflation. However, the inflation is still within a reasonable amount of the nominal level. It should be noted that the Z6 test's Type I error rates for alpha 0.01 are in control if $t_{n-1, \alpha}$ is used in the critical values. Therefore, if the practitioner is very concerned with Type I error, it is recommended that the Z6 test with $t_{n-1, \alpha}$ should be used for small alphas. In addition, since the method involves higher moments such as $k_{6}$ and has $(n-5)$ in the denominator of $k_{6}$, it is recommended that sample sizes of 30 or more be used. Even so, the simulation study found the Type I error rates for the $\mathrm{Z} 6$ test to be reasonable for sample sizes of 20 . 
Table 1. Comparison of Type I Error Rates when $n=40$, Skewed Distributions

\begin{tabular}{|c|c|c|c|c|c|}
\hline \multirow{2}{*}{$\begin{array}{l}\text { Distribution } \\
\text { (skewness) }\end{array}$} & \multicolumn{4}{|c|}{$\alpha=0.01$} & \multirow[b]{2}{*}{ Z6 } \\
\hline & $\chi^{2}, \chi_{r}^{2}$ & $\mathrm{Zs}$ & $\mathrm{Zh}$ & $\mathrm{Z} 2$ & \\
\hline $\begin{array}{l}\text { IG }(1.0,0.1) \\
(9.49)\end{array}$ & $\begin{array}{l}.1616 \\
.0429\end{array}$ & $\begin{array}{l}.0259 \\
.0250 \\
.0237\end{array}$ & $\begin{array}{l}.0004 \\
.0003 \\
.0003\end{array}$ & $\begin{array}{l}.0001 \\
.0000 \\
.0000\end{array}$ & $\begin{array}{l}.0121 \\
.0110 \\
.0100\end{array}$ \\
\hline $\begin{array}{l}\text { Weibull }(1.0,0.5) \\
(6.62)\end{array}$ & $\begin{array}{l}.1522 \\
.0349\end{array}$ & $\begin{array}{l}.0198 \\
.0188 \\
.0177\end{array}$ & $\begin{array}{l}.0012 \\
.0011 \\
.0010\end{array}$ & $\begin{array}{l}.0001 \\
.0001 \\
.0001\end{array}$ & $\begin{array}{l}.0090 \\
.0082 \\
.0074\end{array}$ \\
\hline $\begin{array}{l}\mathrm{LN}(0,1) \\
(6.18)\end{array}$ & $\begin{array}{l}.1325 \\
.0274\end{array}$ & $\begin{array}{l}.0156 \\
.0148 \\
.0141\end{array}$ & $\begin{array}{l}.0012 \\
.0011 \\
.0009\end{array}$ & $\begin{array}{l}.0001 \\
.0001 \\
.0000\end{array}$ & $\begin{array}{l}.0073 \\
.0065 \\
.0057\end{array}$ \\
\hline $\begin{array}{l}\mathrm{IG}(1.0,0.25) \\
(6.00)\end{array}$ & $\begin{array}{l}.1671 \\
.0349\end{array}$ & $\begin{array}{l}.0192 \\
.0179 \\
.0168\end{array}$ & $\begin{array}{l}.0014 \\
.0013 \\
.0011\end{array}$ & $\begin{array}{l}.0002 \\
.0001 \\
.0001\end{array}$ & $\begin{array}{l}.0093 \\
.0082 \\
.0074\end{array}$ \\
\hline$\underset{(5.16)}{\operatorname{Gamma}}(1.0,0.15)$ & $\begin{array}{l}.1704 \\
.0322\end{array}$ & $\begin{array}{l}.0166 \\
.0154 \\
.0144\end{array}$ & $\begin{array}{l}.0025 \\
.0024 \\
.0022\end{array}$ & $\begin{array}{l}.0003 \\
.0003 \\
.0003\end{array}$ & $\begin{array}{l}.0092 \\
.0081 \\
.0073\end{array}$ \\
\hline $\begin{array}{l}\mathrm{IG}(1.0,0.5) \\
(4.24)\end{array}$ & $\begin{array}{l}.1538 \\
.0271\end{array}$ & $\begin{array}{l}.0135 \\
.0126 \\
.0117\end{array}$ & $\begin{array}{l}.0032 \\
.0029 \\
.0028\end{array}$ & $\begin{array}{l}.0005 \\
.0004 \\
.0004\end{array}$ & $\begin{array}{l}.0077 \\
.0069 \\
.0061\end{array}$ \\
\hline $\begin{array}{l}\text { Chi(1) } \\
(2.83)\end{array}$ & $\begin{array}{l}.1282 \\
.0194\end{array}$ & $\begin{array}{l}.0113 \\
.0102 \\
.0094\end{array}$ & $\begin{array}{l}.0073 \\
.0069 \\
.0065\end{array}$ & $\begin{array}{l}.0019 \\
.0017 \\
.0015\end{array}$ & $\begin{array}{l}.0094 \\
.0085 \\
.0077\end{array}$ \\
\hline $\begin{array}{l}\operatorname{Exp}(1.0) \\
(2.00)\end{array}$ & $\begin{array}{l}.0949 \\
.0159\end{array}$ & $\begin{array}{l}.0119 \\
.0110 \\
.0100\end{array}$ & $\begin{array}{l}.0115 \\
.0109 \\
.0103\end{array}$ & $\begin{array}{l}.0045 \\
.0041 \\
.0037\end{array}$ & $\begin{array}{l}.0116 \\
.0104 \\
.0097\end{array}$ \\
\hline $\begin{array}{l}\text { Chi(2) } \\
(2.00)\end{array}$ & $\begin{array}{l}.0922 \\
.0150\end{array}$ & $\begin{array}{l}.0114 \\
.0103 \\
.0095\end{array}$ & $\begin{array}{l}.0114 \\
.0107 \\
.0100\end{array}$ & $\begin{array}{l}.0045 \\
.0041 \\
.0038\end{array}$ & $\begin{array}{l}.0109 \\
.0099 \\
.0091\end{array}$ \\
\hline $\begin{array}{l}\text { Barnes2 } \\
(1.75)\end{array}$ & $\begin{array}{l}.0716 \\
.0127\end{array}$ & $\begin{array}{l}.0141 \\
.0127 \\
.0116\end{array}$ & $\begin{array}{l}.0154 \\
.0146 \\
.0138\end{array}$ & $\begin{array}{l}.0079 \\
.0072 \\
.0065\end{array}$ & $\begin{array}{l}.0150 \\
.0137 \\
.0124\end{array}$ \\
\hline $\begin{array}{l}\mathrm{IG}(1.0,25.0) \\
(0.60)\end{array}$ & $\begin{array}{l}.0217 \\
.0092\end{array}$ & $\begin{array}{l}.0102 \\
.0090 \\
.0081\end{array}$ & $\begin{array}{l}.0113 \\
.0104 \\
.0093\end{array}$ & $\begin{array}{l}.0089 \\
.0078 \\
.0067\end{array}$ & $\begin{array}{l}.0107 \\
.0095 \\
.0084\end{array}$ \\
\hline
\end{tabular}

NOTE: Entries are the estimated proportion of samples rejected in 100,000 simulated samples for $\mathrm{Zs}$, Zh, $\mathrm{Z} 2$, and Z6 test using $z_{\alpha},\left(z_{\alpha}+t_{\alpha, n-1}\right) / 2$, and $t_{\alpha, n-1}$ critical points (first, second, and third numbers in column Zs, Zh, Z2, and Z6) and chi-square and robust chi-square test (first and second) on the column $\chi^{2}, \chi_{r}^{2}$. 
196 RIGHT-TAILED TESTING OF VARIANCE FOR NON-NORMAL DISTRIBUTIONS

Table 1 (continued). Comparison of Type I Error Rates when n=40, Skewed Distributions

\begin{tabular}{|c|c|c|c|c|c|}
\hline Distribution & & $\alpha=0$ & & & \\
\hline (skewness) & $\chi^{2}, \chi_{r}^{2}$ & Zs & $\mathrm{Zh}$ & $\mathrm{Z} 2$ & Z6 \\
\hline $\begin{array}{l}\overline{\mathrm{IG}(1.0,0.1)} \\
(9.49)\end{array}$ & $\begin{array}{l}.1859 \\
.0761\end{array}$ & $\begin{array}{l}.0532 \\
.0520 \\
.0509\end{array}$ & $\begin{array}{l}.0015 \\
.0015 \\
.0014\end{array}$ & $\begin{array}{l}.0007 \\
.0007 \\
.0006\end{array}$ & $\begin{array}{l}.0448 \\
.0433 \\
.0419\end{array}$ \\
\hline $\begin{array}{l}\text { Weibull(1.0,0.5) } \\
(6.62)\end{array}$ & $\begin{array}{l}.1899 \\
.0683\end{array}$ & $\begin{array}{l}.0467 \\
.0454 \\
.0442\end{array}$ & $\begin{array}{l}.0037 \\
.0035 \\
.0033\end{array}$ & $\begin{array}{l}.0017 \\
.0016 \\
.0015\end{array}$ & $\begin{array}{l}.0402 \\
.0387 \\
.0372\end{array}$ \\
\hline $\begin{array}{l}\operatorname{LN}(0,1) \\
(6.18)\end{array}$ & $\begin{array}{l}.1701 \\
.0610\end{array}$ & $\begin{array}{l}.0415 \\
.0404 \\
.0392\end{array}$ & $\begin{array}{l}.0043 \\
.0040 \\
.0039\end{array}$ & $\begin{array}{l}.0022 \\
.0021 \\
.0019\end{array}$ & $\begin{array}{l}.0362 \\
.0347 \\
.0331\end{array}$ \\
\hline $\begin{array}{l}\mathrm{IG}(1.0,0.25) \\
(6.00)\end{array}$ & $\begin{array}{l}.1992 \\
.0719\end{array}$ & $\begin{array}{l}.0479 \\
.0467 \\
.0454\end{array}$ & $\begin{array}{l}.0446 \\
.0437 \\
.0418\end{array}$ & $\begin{array}{l}.0022 \\
.0019 \\
.0017\end{array}$ & $\begin{array}{l}.0417 \\
.0401 \\
.0385\end{array}$ \\
\hline $\begin{array}{l}\operatorname{Gamma}(1.0,0.15) \\
(5.16)\end{array}$ & $\begin{array}{l}.2148 \\
.0743\end{array}$ & $\begin{array}{l}.0486 \\
.0469 \\
.0454\end{array}$ & $\begin{array}{l}.0078 \\
.0075 \\
.0072\end{array}$ & $\begin{array}{l}.0043 \\
.0039 \\
.0035\end{array}$ & $\begin{array}{l}.0430 \\
.0412 \\
.0397\end{array}$ \\
\hline $\begin{array}{l}\mathrm{IG}(1.0,0.5) \\
(4.24)\end{array}$ & $\begin{array}{l}.1994 \\
.0672\end{array}$ & $\begin{array}{l}.0442 \\
.0423 \\
.0408\end{array}$ & $\begin{array}{l}.0094 \\
.0090 \\
.0087\end{array}$ & $\begin{array}{l}.0050 \\
.0046 \\
.0043\end{array}$ & $\begin{array}{l}.0395 \\
.0378 \\
.0360\end{array}$ \\
\hline $\begin{array}{l}\text { Chi(1) } \\
(2.83)\end{array}$ & $\begin{array}{l}.1906 \\
.0622\end{array}$ & $\begin{array}{l}.0439 \\
.0421 \\
.0406\end{array}$ & $\begin{array}{l}.0203 \\
.0197 \\
.0191\end{array}$ & $\begin{array}{l}.0136 \\
.0130 \\
.0124\end{array}$ & $\begin{array}{l}.0431 \\
.0416 \\
.0397\end{array}$ \\
\hline $\begin{array}{l}\operatorname{Exp}(1.0) \\
(2.00)\end{array}$ & $\begin{array}{l}.1583 \\
.0559\end{array}$ & $\begin{array}{l}.0441 \\
.0424 \\
.0408\end{array}$ & $\begin{array}{l}.0299 \\
.0289 \\
.0279\end{array}$ & $\begin{array}{l}.0229 \\
.0218 \\
.0209\end{array}$ & $\begin{array}{l}.0460 \\
.0442 \\
.0425\end{array}$ \\
\hline $\begin{array}{l}\text { Chi(2) } \\
(2.00)\end{array}$ & $\begin{array}{l}.1557 \\
.0545\end{array}$ & $\begin{array}{l}.0430 \\
.0414 \\
.0399\end{array}$ & $\begin{array}{l}.0293 \\
.0285 \\
.0278\end{array}$ & $\begin{array}{l}.0226 \\
.0214 \\
.0204\end{array}$ & $\begin{array}{l}.0453 \\
.0434 \\
.0415\end{array}$ \\
\hline $\begin{array}{l}\text { Barnes } 2 \\
(1.75)\end{array}$ & $\begin{array}{l}.1414 \\
.0549\end{array}$ & $\begin{array}{l}.0485 \\
.0466 \\
.0451\end{array}$ & $\begin{array}{l}.0388 \\
.0376 \\
.0364\end{array}$ & $\begin{array}{l}.0340 \\
.0324 \\
.0309\end{array}$ & $\begin{array}{l}.0531 \\
.0511 \\
.0493\end{array}$ \\
\hline $\begin{array}{l}\mathrm{IG}(1.0,25.0) \\
(0.60)\end{array}$ & $\begin{array}{l}.0732 \\
.0442\end{array}$ & $\begin{array}{l}.0429 \\
.0413 \\
.0397\end{array}$ & $\begin{array}{l}.0407 \\
.0390 \\
.0376\end{array}$ & $\begin{array}{l}.0429 \\
.0410 \\
.0389\end{array}$ & $\begin{array}{l}.0498 \\
.0477 \\
.0454\end{array}$ \\
\hline
\end{tabular}

NOTE: Entries are the estimated proportion of samples rejected in 100,000 simulated samples for Zs, $\mathrm{Zh}, \mathrm{Z} 2$, and Z6 test using $z_{\alpha},\left(z_{\alpha}+t_{\alpha, n-1}\right) / 2$, and $t_{\alpha, n-1}$ critical points (first, second, and third numbers in column Zs, Zh, Z2, and Z6) and chi-square and robust chi-square test (first and second) on the column $\chi^{2}, \chi_{r}^{2}$. 
Table 2. Comparison of Type I Error Rates when n=20, Skewed Distributions

\begin{tabular}{|c|c|c|c|c|c|}
\hline \multirow{2}{*}{$\begin{array}{l}\text { Distribution } \\
\text { (skewness) }\end{array}$} & \multicolumn{5}{|c|}{$\alpha=0.01$} \\
\hline & $\chi^{2}, \chi_{r}^{2}$ & Zs & $\mathrm{Zh}$ & $\mathrm{Z} 2$ & Z6 \\
\hline $\begin{array}{l}\text { IG }(1.0,0.1) \\
(9.49)\end{array}$ & $\begin{array}{l}.1215 \\
.0443\end{array}$ & $\begin{array}{l}.0342 \\
.0321 \\
.0302\end{array}$ & $\begin{array}{l}.0003 \\
.0003 \\
.0003\end{array}$ & $\begin{array}{l}.0003 \\
.0003 \\
.0002\end{array}$ & $\begin{array}{l}.0149 \\
.0122 \\
.0104\end{array}$ \\
\hline $\begin{array}{l}\text { Weibull(1.0,0.5) } \\
(6.62)\end{array}$ & $\begin{array}{l}.1227 \\
.0386\end{array}$ & $\begin{array}{l}.0294 \\
.0270 \\
.0249\end{array}$ & $\begin{array}{l}.0012 \\
.0011 \\
.0009\end{array}$ & $\begin{array}{l}.0012 \\
.0011 \\
.0009\end{array}$ & $\begin{array}{l}.0139 \\
.0115 \\
.0098\end{array}$ \\
\hline $\begin{array}{l}\operatorname{LN}(0,1) \\
(6.18)\end{array}$ & $\begin{array}{l}.1082 \\
.0316\end{array}$ & $\begin{array}{l}.0246 \\
.0226 \\
.0209\end{array}$ & $\begin{array}{l}.0013 \\
.0012 \\
.0010\end{array}$ & $\begin{array}{l}.0014 \\
.0012 \\
.0011\end{array}$ & $\begin{array}{l}.0119 \\
.0100 \\
.0083\end{array}$ \\
\hline $\begin{array}{l}\mathrm{IG}(1.0,0.25) \\
(6.00)\end{array}$ & $\begin{array}{l}.1295 \\
.0406\end{array}$ & $\begin{array}{l}.0307 \\
.0281 \\
.0258\end{array}$ & $\begin{array}{l}.0015 \\
.0014 \\
.0013\end{array}$ & $\begin{array}{l}.0015 \\
.0014 \\
.0012\end{array}$ & $\begin{array}{l}.0142 \\
.0120 \\
.0098\end{array}$ \\
\hline$\underset{(5.16)}{\operatorname{Gamma}}(1.0,0.15)$ & $\begin{array}{l}.1408 \\
.0396\end{array}$ & $\begin{array}{l}.0296 \\
.0269 \\
.0243\end{array}$ & $\begin{array}{l}.0024 \\
.0021 \\
.0019\end{array}$ & $\begin{array}{l}.0025 \\
.0021 \\
.0018\end{array}$ & $\begin{array}{l}.0152 \\
.0128 \\
.0108\end{array}$ \\
\hline $\begin{array}{l}\mathrm{IG}(1.0,0.5) \\
(4.24)\end{array}$ & $\begin{array}{l}.1272 \\
.0336\end{array}$ & $\begin{array}{l}.0258 \\
.0231 \\
.0208\end{array}$ & $\begin{array}{l}.0029 \\
.0024 \\
.0022\end{array}$ & $\begin{array}{l}.0030 \\
.0026 \\
.0023\end{array}$ & $\begin{array}{l}.0141 \\
.0119 \\
.0102\end{array}$ \\
\hline $\begin{array}{l}\text { Chi(1) } \\
(2.83)\end{array}$ & $\begin{array}{l}.1096 \\
.0265\end{array}$ & $\begin{array}{l}.0228 \\
.0201 \\
.0176\end{array}$ & $\begin{array}{l}.0067 \\
.0059 \\
.0051\end{array}$ & $\begin{array}{l}.0079 \\
.0070 \\
.0061\end{array}$ & $\begin{array}{l}.0185 \\
.0161 \\
.0139\end{array}$ \\
\hline $\begin{array}{l}\operatorname{Exp}(1.0) \\
(2.00)\end{array}$ & $\begin{array}{l}.0810 \\
.0202\end{array}$ & $\begin{array}{l}.0203 \\
.0175 \\
.0153\end{array}$ & $\begin{array}{l}.0092 \\
.0079 \\
.0067\end{array}$ & $\begin{array}{l}.0107 \\
.0093 \\
.0080\end{array}$ & $\begin{array}{l}.0191 \\
.0165 \\
.0144\end{array}$ \\
\hline $\begin{array}{l}\text { Chi(2) } \\
(2.00)\end{array}$ & $\begin{array}{l}.0825 \\
.0205\end{array}$ & $\begin{array}{l}.0206 \\
.0180 \\
.0156\end{array}$ & $\begin{array}{l}.0095 \\
.0083 \\
.0071\end{array}$ & $\begin{array}{l}.0111 \\
.0097 \\
.0082\end{array}$ & $\begin{array}{l}.0196 \\
.0168 \\
.0145\end{array}$ \\
\hline $\begin{array}{l}\text { Barnes2 } \\
(1.75)\end{array}$ & $\begin{array}{l}.0680 \\
.0192 \\
.0171\end{array}$ & $\begin{array}{l}.0228 \\
.0198 \\
.0097\end{array}$ & $\begin{array}{l}.0127 \\
.0112 \\
.0119\end{array}$ & $\begin{array}{l}.0159 \\
.0137 \\
.0180\end{array}$ & $\begin{array}{l}.0238 \\
.0206\end{array}$ \\
\hline $\begin{array}{l}\mathrm{IG}(1.0,25.0) \\
(0.60)\end{array}$ & $\begin{array}{l}.0213 \\
.0095\end{array}$ & $\begin{array}{l}.0134 \\
.0113 \\
.0095\end{array}$ & $\begin{array}{l}.0105 \\
.0087 \\
.0072\end{array}$ & $\begin{array}{l}.0098 \\
.0079 \\
.0064\end{array}$ & $\begin{array}{l}.0120 \\
.0095 \\
.0076\end{array}$ \\
\hline
\end{tabular}

NOTE: Entries are the estimated proportion of samples rejected in 100,000 simulated samples for $\mathrm{Zs}, \mathrm{Zh}, \mathrm{Z} 2$, and Z6 test using $z_{\alpha},\left(z_{\alpha}+t_{\alpha, n-1}\right) / 2$, and $t_{\alpha, n-1}$ critical points (first, second, and third numbers in column Zs, Zh, Z2, and Z6) and chi-square and robust chi-square test (first and second) on the column $\chi^{2}, \chi_{r}^{2}$. 
198 RIGHT-TAILED TESTING OF VARIANCE FOR NON-NORMAL DISTRIBUTIONS

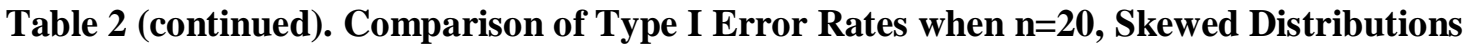

\begin{tabular}{|c|c|c|c|c|c|}
\hline \multirow{2}{*}{$\begin{array}{l}\text { Distribution } \\
\text { (skewness) }\end{array}$} & \multicolumn{5}{|c|}{$\alpha=0.05$} \\
\hline & $\chi^{2}, \chi_{r}^{2}$ & Zs & $\mathrm{Zh}$ & $\mathrm{Z} 2$ & Z6 \\
\hline $\begin{array}{l}\text { IG }(1.0,0.1) \\
(9.49)\end{array}$ & $\begin{array}{l}.1451 \\
.0736\end{array}$ & $\begin{array}{l}.0566 \\
.0547 \\
.0530\end{array}$ & $\begin{array}{l}.0014 \\
.0013 \\
.0011\end{array}$ & $\begin{array}{c}.0015 \\
.0014 \\
.0012\end{array}$ & $\begin{array}{l}.0459 \\
+.0430 \\
.0399\end{array}$ \\
\hline $\begin{array}{l}\text { Weibull(1.0,0.5) } \\
(6.62)\end{array}$ & $\begin{array}{l}.1538 \\
.0706\end{array}$ & $\begin{array}{l}.0534 \\
.0514 \\
.0493\end{array}$ & $\begin{array}{l}.0033 \\
.0031 \\
.0028\end{array}$ & $\begin{array}{l}.0039 \\
.0035 \\
.0031\end{array}$ & $\begin{array}{l}.0444 \\
.0412 \\
.0385\end{array}$ \\
\hline $\begin{array}{l}\operatorname{LN}(0,1) \\
(6.18)\end{array}$ & $\begin{array}{l}.1377 \\
.0603\end{array}$ & $\begin{array}{l}.0471 \\
.0451 \\
.0431\end{array}$ & $\begin{array}{l}.0482 \\
.0435 \\
.0406\end{array}$ & $\begin{array}{l}.0057 \\
.0051 \\
.0046\end{array}$ & $\begin{array}{l}.0397 \\
.0369 \\
.0343\end{array}$ \\
\hline $\begin{array}{l}\mathrm{IG}(1.0,0.25) \\
(6.00)\end{array}$ & $\begin{array}{l}.1652 \\
.0760\end{array}$ & $\begin{array}{l}.0579 \\
.0552 \\
.0528\end{array}$ & $\begin{array}{l}.0046 \\
.0041 \\
.0038\end{array}$ & $\begin{array}{l}.0053 \\
.0047 \\
.0043\end{array}$ & $\begin{array}{l}.0473 \\
.0437 \\
.0407\end{array}$ \\
\hline $\begin{array}{l}\underset{(5.16)}{\operatorname{Gamma}}(1.0,0.15) \\
\end{array}$ & $\begin{array}{l}.1805 \\
.0575\end{array}$ & $\begin{array}{l}.0604 \\
.0568 \\
.0549\end{array}$ & $\begin{array}{l}.0073 \\
.0069 \\
.0064\end{array}$ & $\begin{array}{l}.0079 \\
.0072 \\
.0064\end{array}$ & $\begin{array}{l}.0505 \\
.0471 \\
.0438\end{array}$ \\
\hline $\begin{array}{l}\mathrm{IG}(1.0,0.5) \\
(4.24)\end{array}$ & $\begin{array}{l}.1686 \\
.0725\end{array}$ & $\begin{array}{l}.0560 \\
.0535 \\
.0509\end{array}$ & $\begin{array}{l}.0089 \\
.0083 \\
.0077\end{array}$ & $\begin{array}{l}.0104 \\
.0095 \\
.0087\end{array}$ & $\begin{array}{l}.0484 \\
.0446 \\
.0416\end{array}$ \\
\hline $\begin{array}{l}\text { Chi(1) } \\
(2.83)\end{array}$ & $\begin{array}{l}.1635 \\
.0669\end{array}$ & $\begin{array}{l}.0545 \\
.0515 \\
.0484\end{array}$ & $\begin{array}{l}.0176 \\
.0165 \\
.0155\end{array}$ & $\begin{array}{l}.0215 \\
.0200 \\
.0186\end{array}$ & $\begin{array}{l}.0523 \\
.0486 \\
.0455\end{array}$ \\
\hline $\begin{array}{l}\operatorname{Exp}(1.0) \\
(2.00)\end{array}$ & $\begin{array}{l}.1394 \\
.0604\end{array}$ & $\begin{array}{l}.0529 \\
.0496 \\
.0468\end{array}$ & $\begin{array}{l}.0260 \\
.0241 \\
.0226\end{array}$ & $\begin{array}{l}.0313 \\
.0291 \\
.0272\end{array}$ & $\begin{array}{l}.0544 \\
.0506 \\
.0473\end{array}$ \\
\hline $\begin{array}{l}\text { Chi(2) } \\
(2.00)\end{array}$ & $\begin{array}{l}.1406 \\
.0605\end{array}$ & $\begin{array}{l}.0543 \\
.0511 \\
.0482\end{array}$ & $\begin{array}{l}.0264 \\
.0245 \\
.0229\end{array}$ & $\begin{array}{l}.0317 \\
.0293 \\
.0273\end{array}$ & $\begin{array}{l}.0565 \\
.0524 \\
.0489\end{array}$ \\
\hline $\begin{array}{l}\text { Barnes2 } \\
(1.75)\end{array}$ & $\begin{array}{l}.1307 \\
.0587 \\
.0499\end{array}$ & $\begin{array}{l}.0560 \\
.0530 \\
.0302\end{array}$ & $\begin{array}{l}.0342 \\
.0321 \\
.0364\end{array}$ & $\begin{array}{l}.0416 \\
.0389 \\
.0542\end{array}$ & $\begin{array}{l}.0617 \\
.0577\end{array}$ \\
\hline $\begin{array}{l}\mathrm{IG}(1.0,25.0) \\
(0.60)\end{array}$ & $\begin{array}{l}.0687 \\
.0437\end{array}$ & $\begin{array}{l}.0449 \\
.0419 \\
.0388\end{array}$ & $\begin{array}{l}.0377 \\
.0349 \\
.0322\end{array}$ & $\begin{array}{l}.0433 \\
.0398 \\
.0365\end{array}$ & $\begin{array}{l}.0507 \\
.0464 \\
.0424\end{array}$ \\
\hline
\end{tabular}

NOTE: Entries are the estimated proportion of samples rejected in 100,000 simulated samples for $\mathrm{Zs}, \mathrm{Zh}, \mathrm{Z}$, and Z6 test using $z_{\alpha},\left(z_{\alpha}+t_{\alpha, n-1}\right) / 2$, and $t_{\alpha, n-1}$ critical points (first, second, and third numbers in column Zs, Zh, Z2, and Z6) and chi-square and robust chi-square test (first and second) on the column $\chi^{2}, \chi_{r}^{2}$. 
Table 3. Comparison of Type I Error Rates when n=40, Heavy-tailed Distributions

\begin{tabular}{|c|c|c|c|c|c|}
\hline \multirow{2}{*}{$\begin{array}{l}\text { Distribution } \\
\text { (kurtosis) }\end{array}$} & \multicolumn{5}{|c|}{$\alpha=0.01$} \\
\hline & $\chi^{2}, \chi_{r}^{2}$ & $\mathrm{Zs}$ & $\mathrm{Zh}$ & $\mathrm{Z} 2$ & Z6 \\
\hline $\begin{array}{l}\text { Barnes3 } \\
(75.1)\end{array}$ & $\begin{array}{l}.1269 \\
.0280\end{array}$ & $\begin{array}{l}.0167 \\
.0158 \\
.0151\end{array}$ & $\begin{array}{l}.0001 \\
.0001 \\
.0001\end{array}$ & $\begin{array}{l}.0000 \\
.0000 \\
.0000\end{array}$ & $\begin{array}{l}.0060 \\
.0052 \\
.0047\end{array}$ \\
\hline $\begin{array}{l}\mathrm{T}(5) \\
(6.00)\end{array}$ & $\begin{array}{l}.0629 \\
.0111\end{array}$ & $\begin{array}{l}.0075 \\
.0066 \\
.0059\end{array}$ & $\begin{array}{l}.0084 \\
.0079 \\
.0074\end{array}$ & $\begin{array}{l}.0027 \\
.0024 \\
.0021\end{array}$ & $\begin{array}{l}.0058 \\
.0050 \\
.0045\end{array}$ \\
\hline $\begin{array}{l}\text { Barnes } 1 \\
(6.00)\end{array}$ & $\begin{array}{l}.1081 \\
.0188\end{array}$ & $\begin{array}{l}.0118 \\
.0105 \\
.0093\end{array}$ & $\begin{array}{l}.0126 \\
.0119 \\
.0111\end{array}$ & $\begin{array}{l}.0021 \\
.0019 \\
.0017\end{array}$ & $\begin{array}{l}.0089 \\
.0078 \\
.0068\end{array}$ \\
\hline $\begin{array}{l}\mathrm{T}(6) \\
(3.00)\end{array}$ & $\begin{array}{l}.0526 \\
.0103\end{array}$ & $\begin{array}{l}.0085 \\
.0076 \\
.0067\end{array}$ & $\begin{array}{l}.0108 \\
.0100 \\
.0092\end{array}$ & $\begin{array}{l}.0044 \\
.0040 \\
.0034\end{array}$ & $\begin{array}{l}.0075 \\
.0067 \\
.0059\end{array}$ \\
\hline$\underset{(3.00)}{\operatorname{Laplace}(2.0,1.0)}$ & $\begin{array}{l}.0608 \\
.0124\end{array}$ & $\begin{array}{l}.0099 \\
.0089 \\
.0080\end{array}$ & $\begin{array}{l}.0138 \\
.0130 \\
.0120\end{array}$ & $\begin{array}{l}.0043 \\
.0038 \\
.0034\end{array}$ & $\begin{array}{l}.0092 \\
.0081 \\
.0072\end{array}$ \\
\hline $\begin{array}{l}\operatorname{JTB}(4.0,1.0) \\
(0.78)\end{array}$ & $\begin{array}{l}.0246 \\
.0098\end{array}$ & $\begin{array}{l}.0103 \\
.0092 \\
.0084\end{array}$ & $\begin{array}{l}.0127 \\
.0118 \\
.0109\end{array}$ & $\begin{array}{l}.0082 \\
.0074 \\
.0067\end{array}$ & $\begin{array}{l}.0106 \\
.0095 \\
.0084\end{array}$ \\
\hline $\begin{array}{l}\mathrm{T}(16) \\
(0.50)\end{array}$ & $\begin{array}{l}.0198 \\
.0095\end{array}$ & $\begin{array}{l}.0103 \\
.0092 \\
.0083\end{array}$ & $\begin{array}{l}.0118 \\
.0107 \\
.0098\end{array}$ & $\begin{array}{l}.0088 \\
.0079 \\
.0070\end{array}$ & $\begin{array}{l}.0104 \\
.0092 \\
.0083\end{array}$ \\
\hline $\begin{array}{l}\operatorname{JTB}(1.25,0.5) \\
(0.24)\end{array}$ & $\begin{array}{l}.0134 \\
.0089\end{array}$ & $\begin{array}{l}.0102 \\
.0091 \\
.0081\end{array}$ & $\begin{array}{l}.0112 \\
.0101 \\
.0090\end{array}$ & $\begin{array}{l}.0097 \\
.0086 \\
.0075\end{array}$ & $\begin{array}{l}.0108 \\
.0095 \\
.0083\end{array}$ \\
\hline $\begin{array}{l}\mathrm{T}(32) \\
(0.21)\end{array}$ & $\begin{array}{l}.0139 \\
.0083\end{array}$ & $\begin{array}{l}.0091 \\
.0084 \\
.0076\end{array}$ & $\begin{array}{l}.0100 \\
.0093 \\
.0085\end{array}$ & $\begin{array}{l}.0084 \\
.0075 \\
.0067\end{array}$ & $\begin{array}{l}.0093 \\
.0083 \\
.0074\end{array}$ \\
\hline $\begin{array}{l}\operatorname{JTB}(2.0,0.5) \\
(-0.30)\end{array}$ & $\begin{array}{l}.0061 \\
.0055\end{array}$ & $\begin{array}{l}.0064 \\
.0056 \\
.0049\end{array}$ & $\begin{array}{l}.0068 \\
.0059 \\
.0052\end{array}$ & $\begin{array}{l}.0060 \\
.0051 \\
.0043\end{array}$ & $\begin{array}{l}.0061 \\
.0052 \\
.0044\end{array}$ \\
\hline
\end{tabular}

NOTE: Entries are the estimated proportion of samples rejected in 100,000 simulated samples for Zs, Zh, Z2, and Z6 test using $z_{\alpha},\left(z_{\alpha}+t_{\alpha, n-1}\right) / 2$, and $t_{\alpha, n-1}$ critical points (first, second, and third numbers in column Zs, $\mathrm{Zh}, \mathrm{Z2}$, and Z6) and chi-square and robust chi-square test (first and second) on the column $\chi^{2}, \chi_{r}^{2}$. 
Table 3 (continued). Comparison of Type I Error Rates when $\mathrm{n}=40$, Heavy-tailed Distributions

\begin{tabular}{|c|c|c|c|c|c|}
\hline \multirow{2}{*}{$\begin{array}{l}\text { Distribution } \\
\text { (kurtosis) }\end{array}$} & \multicolumn{5}{|c|}{$\alpha=0.05$} \\
\hline & $\chi^{2}, \chi_{r}^{2}$ & $\mathrm{Zs}$ & $\mathrm{Zh}$ & $\mathrm{Z} 2$ & Z6 \\
\hline $\begin{array}{l}\text { Barnes3 } \\
(75.1)\end{array}$ & $\begin{array}{l}.1554 \\
.0590\end{array}$ & $\begin{array}{l}.0390 \\
.0380 \\
.0371\end{array}$ & $\begin{array}{l}.0011 \\
.0011 \\
.0010\end{array}$ & $\begin{array}{l}.0003 \\
.0002 \\
.0002\end{array}$ & $\begin{array}{l}.0315 \\
.0302 \\
.0290\end{array}$ \\
\hline $\begin{array}{l}\mathrm{T}(5) \\
(6.00)\end{array}$ & $\begin{array}{l}.1184 \\
.0456\end{array}$ & $\begin{array}{l}.0362 \\
.0348 \\
.0332\end{array}$ & $\begin{array}{l}.0262 \\
.0254 \\
.0247\end{array}$ & $\begin{array}{l}.0198 \\
.0188 \\
.0178\end{array}$ & $\begin{array}{l}.0369 \\
.0352 \\
.0335\end{array}$ \\
\hline $\begin{array}{l}\text { Barnes 1 } \\
(6.00)\end{array}$ & $\begin{array}{l}.1786 \\
.0655\end{array}$ & $\begin{array}{l}.0492 \\
.0472 \\
.0453\end{array}$ & $\begin{array}{l}.0327 \\
.0317 \\
.0308\end{array}$ & $\begin{array}{l}.0201 \\
.0190 \\
.0179\end{array}$ & $\begin{array}{l}.0484 \\
.0462 \\
.0444\end{array}$ \\
\hline $\begin{array}{l}\mathrm{T}(6) \\
(3.00)\end{array}$ & $\begin{array}{l}.1054 \\
.0449\end{array}$ & $\begin{array}{l}.0376 \\
.0360 \\
.0345\end{array}$ & $\begin{array}{l}.0310 \\
.0300 \\
.0290\end{array}$ & $\begin{array}{l}.0257 \\
.0243 \\
.0231\end{array}$ & $\begin{array}{l}.0400 \\
.0381 \\
.0363\end{array}$ \\
\hline $\begin{array}{l}\text { Laplace }(2.0,1.0) \\
(3.00)\end{array}$ & $\begin{array}{l}.1263 \\
.0500\end{array}$ & $\begin{array}{l}.0417 \\
.0400 \\
.0385\end{array}$ & $\begin{array}{l}.0359 \\
.0349 \\
.0338\end{array}$ & $\begin{array}{l}.0268 \\
.0254 \\
.0241\end{array}$ & $\begin{array}{l}.0449 \\
.0431 \\
.0413\end{array}$ \\
\hline $\begin{array}{l}\operatorname{JTB}(4.0,1.0) \\
(0.78)\end{array}$ & $\begin{array}{l}.0770 \\
.0464\end{array}$ & $\begin{array}{l}.0447 \\
.0429 \\
.0414\end{array}$ & $\begin{array}{l}.0428 \\
.0410 \\
.0396\end{array}$ & $\begin{array}{l}.0429 \\
.0409 \\
.0391\end{array}$ & $\begin{array}{l}.0506 \\
.0487 \\
.0466\end{array}$ \\
\hline $\begin{array}{l}\mathrm{T}(16) \\
(0.50)\end{array}$ & $\begin{array}{l}.0683 \\
.0448\end{array}$ & $\begin{array}{l}.0436 \\
.0419 \\
.0402\end{array}$ & $\begin{array}{l}.0419 \\
.0402 \\
.0388\end{array}$ & $\begin{array}{l}.0438 \\
.0420 \\
.0401\end{array}$ & $\begin{array}{l}.0498 \\
.0479 \\
.0457\end{array}$ \\
\hline $\begin{array}{l}\operatorname{JTB}(1.25,0.5) \\
(0.24)\end{array}$ & $\begin{array}{l}.0577 \\
.0441\end{array}$ & $\begin{array}{l}.0445 \\
.0428 \\
.0411\end{array}$ & $\begin{array}{l}.0431 \\
.0414 \\
.0400\end{array}$ & $\begin{array}{l}.0481 \\
.0459 \\
.0442\end{array}$ & $\begin{array}{l}.0515 \\
.0493 \\
.0474\end{array}$ \\
\hline $\begin{array}{l}\mathrm{T}(32) \\
(0.21)\end{array}$ & $\begin{array}{l}.0591 \\
.0444\end{array}$ & $\begin{array}{l}.0444 \\
.0425 \\
.0407\end{array}$ & $\begin{array}{l}.0434 \\
.0419 \\
.0402\end{array}$ & $\begin{array}{l}.0471 \\
.0448 \\
.0430\end{array}$ & $\begin{array}{l}.0510 \\
.0489 \\
.0467\end{array}$ \\
\hline $\begin{array}{l}\operatorname{JTB}(2.0,0.5) \\
(-0.30)\end{array}$ & $\begin{array}{l}.0381 \\
.0348\end{array}$ & $\begin{array}{l}.0344 \\
.0327 \\
.0312\end{array}$ & $\begin{array}{l}.0355 \\
.0338 \\
.0323\end{array}$ & $\begin{array}{l}.0396 \\
.0377 \\
.0359\end{array}$ & $\begin{array}{l}.0405 \\
.0385 \\
.0366\end{array}$ \\
\hline
\end{tabular}

NOTE: Entries are the estimated proportion of samples rejected in 100,000 simulated samples for $\mathrm{Zs}$, Zh, $\mathrm{Z} 2$, and Z6 test using $z_{\alpha},\left(z_{\alpha}+t_{\alpha, n-1}\right) / 2$, and $t_{\alpha, n-1}$ critical points (first, second, and third numbers in column Zs, Zh, Z2, and Z6) and chi-square and robust chi-square test (first and second) on the column $\chi^{2}, \chi_{r}^{2}$. 
Table 4. Comparison of Type I Error Rates when n=20, Heavy-tailed Distributions

\begin{tabular}{|c|c|c|c|c|c|}
\hline \multirow{2}{*}{$\begin{array}{l}\text { Distribution } \\
\text { (kurtosis) }\end{array}$} & \multicolumn{5}{|c|}{$\alpha=0.01$} \\
\hline & $\chi^{2}, \chi_{r}^{2}$ & $\mathrm{Zs}$ & $\mathrm{Zh}$ & $\mathrm{Z} 2$ & Z6 \\
\hline $\begin{array}{l}\text { Barnes3 } \\
(75.1)\end{array}$ & $\begin{array}{l}.0964 \\
.0290\end{array}$ & $\begin{array}{l}.0241 \\
.0221 \\
.0207\end{array}$ & $\begin{array}{l}.0001 \\
.0001 \\
.0001\end{array}$ & $\begin{array}{l}.0001 \\
.0001 \\
.0001\end{array}$ & $\begin{array}{l}.0076 \\
.0062 \\
.0049\end{array}$ \\
\hline $\begin{array}{l}\mathrm{T}(5) \\
(6.00)\end{array}$ & $\begin{array}{l}.0543 \\
.0147\end{array}$ & $\begin{array}{l}.0151 \\
.0125 \\
.0107\end{array}$ & $\begin{array}{l}.0072 \\
.0060 \\
.0052\end{array}$ & $\begin{array}{l}.0056 \\
.0046 \\
.0037\end{array}$ & $\begin{array}{l}.0100 \\
.0082 \\
.0063\end{array}$ \\
\hline $\begin{array}{c}\text { Barnes } 1 \\
(6.00)\end{array}$ & $\begin{array}{l}.0590 \\
.0225\end{array}$ & $\begin{array}{l}.0205 \\
.0178 \\
.0153\end{array}$ & $\begin{array}{l}.0084 \\
.0072 \\
.0062\end{array}$ & $\begin{array}{l}.0059 \\
.0048 \\
.0039\end{array}$ & $\begin{array}{l}.0136 \\
.0111 \\
.0092\end{array}$ \\
\hline $\begin{array}{l}\mathrm{T}(6) \\
(3.00)\end{array}$ & $\begin{array}{l}.0461 \\
.0131\end{array}$ & $\begin{array}{l}.0146 \\
.0122 \\
.0104\end{array}$ & $\begin{array}{l}.0088 \\
.0075 \\
.0062\end{array}$ & $\begin{array}{l}.0070 \\
.0055 \\
.0044\end{array}$ & $\begin{array}{l}.0110 \\
.0088 \\
.0070\end{array}$ \\
\hline $\begin{array}{l}\text { Laplace }(2.0,1.0) \\
(3.00)\end{array}$ & $\begin{array}{l}.0053 \\
.0153\end{array}$ & $\begin{array}{l}.0165 \\
.0138 \\
.0117\end{array}$ & $\begin{array}{l}.0105 \\
.0089 \\
.0077\end{array}$ & $\begin{array}{l}.0083 \\
.0068 \\
.0055\end{array}$ & $\begin{array}{l}.0139 \\
.0113 \\
.0092\end{array}$ \\
\hline $\begin{array}{l}\operatorname{JTB}(4.0,1.0) \\
(0.78)\end{array}$ & $\begin{array}{l}.0238 \\
.0107\end{array}$ & $\begin{array}{l}.0143 \\
.0118 \\
.0098\end{array}$ & $\begin{array}{l}.0115 \\
.0096 \\
.0081\end{array}$ & $\begin{array}{l}.0100 \\
.0079 \\
.0061\end{array}$ & $\begin{array}{l}.0126 \\
.0098 \\
.0076\end{array}$ \\
\hline $\begin{array}{l}\mathrm{T}(16) \\
(0.50)\end{array}$ & $\begin{array}{l}.0184 \\
.0093\end{array}$ & $\begin{array}{l}.0128 \\
.0106 \\
.0089\end{array}$ & $\begin{array}{l}.0104 \\
.0086 \\
.0072\end{array}$ & $\begin{array}{l}.0092 \\
.0073 \\
.0058\end{array}$ & $\begin{array}{l}.0108 \\
.0084 \\
.0066\end{array}$ \\
\hline $\begin{array}{l}\operatorname{JTB}(1.25,0.5) \\
(0.24)\end{array}$ & $\begin{array}{l}.0138 \\
.0094\end{array}$ & $\begin{array}{l}.0138 \\
.0114 \\
.0096\end{array}$ & $\begin{array}{l}.0120 \\
.0099 \\
.0081\end{array}$ & $\begin{array}{l}.0104 \\
.0079 \\
.0062\end{array}$ & $\begin{array}{l}.0115 \\
.0087 \\
.0069\end{array}$ \\
\hline $\begin{array}{l}\mathrm{T}(32) \\
(0.21)\end{array}$ & $\begin{array}{l}.0134 \\
.0079\end{array}$ & $\begin{array}{l}.0121 \\
.0099 \\
.0079\end{array}$ & $\begin{array}{l}.0103 \\
.0084 \\
.0066\end{array}$ & $\begin{array}{l}.0087 \\
.0066 \\
.0050\end{array}$ & $\begin{array}{l}.0101 \\
.0076 \\
.0056\end{array}$ \\
\hline $\begin{array}{l}\operatorname{JTB}(2.0,0.5) \\
(-0.30)\end{array}$ & $\begin{array}{l}.0059 \\
.0051\end{array}$ & $\begin{array}{l}.0091 \\
.0076 \\
.0061\end{array}$ & $\begin{array}{l}.0075 \\
.0059 \\
.0046\end{array}$ & $\begin{array}{l}.0054 \\
.0038 \\
.0026\end{array}$ & $\begin{array}{l}.0057 \\
.0040 \\
.0028\end{array}$ \\
\hline
\end{tabular}

NOTE: Entries are the estimated proportion of samples rejected in 100,000 simulated samples for $\mathrm{Zs}$, Zh, $\mathrm{Z} 2$, and Z6 test using $z_{\alpha},\left(z_{\alpha}+t_{\alpha, n-1}\right) / 2$, and $t_{\alpha, n-1}$ critical points (first, second, and third numbers in column $\mathrm{Zs}, \mathrm{Zh}, \mathrm{Z2}$, and Z6) and chi-square and robust chi-square test (first and second) on the column $\chi^{2}, \chi_{r}^{2}$. 
Table 4 (continued). Comparison of Type I Error Rates when $\mathrm{n}=20$, Heavy-tailed Distributions

\begin{tabular}{|c|c|c|c|c|c|}
\hline \multirow{2}{*}{$\begin{array}{l}\text { Distribution } \\
\text { (kurtosis) }\end{array}$} & \multicolumn{5}{|c|}{$\alpha=0.05$} \\
\hline & $\chi^{2}, \chi_{r}^{2}$ & $\mathrm{Zs}$ & $\mathrm{Zh}$ & $\mathrm{Z} 2$ & Z6 \\
\hline $\begin{array}{l}\text { Barnes3 } \\
(75.1)\end{array}$ & $\begin{array}{l}.1184 \\
.0544\end{array}$ & $\begin{array}{l}.0430 \\
.0414 \\
.0397\end{array}$ & $\begin{array}{l}.0009 \\
.0008 \\
.0007\end{array}$ & $\begin{array}{l}.0007 \\
.0005 \\
.0005\end{array}$ & $\begin{array}{l}.0319 \\
.0294 \\
.0268\end{array}$ \\
\hline $\begin{array}{l}\mathrm{T}(5) \\
(6.00)\end{array}$ & $\begin{array}{l}.1034 \\
.0489\end{array}$ & $\begin{array}{l}.0439 \\
.0409 \\
.0383\end{array}$ & $\begin{array}{l}.0233 \\
.0215 \\
.0199\end{array}$ & $\begin{array}{l}.0249 \\
.0225 \\
.0206\end{array}$ & $\begin{array}{l}.0440 \\
.0398 \\
.0362\end{array}$ \\
\hline $\begin{array}{l}\text { Barnes1 } \\
(6.00)\end{array}$ & $\begin{array}{l}.1509 \\
.0674\end{array}$ & $\begin{array}{l}.0570 \\
.0537 \\
.0502\end{array}$ & $\begin{array}{l}.0244 \\
.0225 \\
.0206\end{array}$ & $\begin{array}{l}.0243 \\
.0220 \\
.0201\end{array}$ & $\begin{array}{l}.0544 \\
.0496 \\
.0456\end{array}$ \\
\hline $\begin{array}{l}\mathrm{T}(6) \\
(3.00)\end{array}$ & $\begin{array}{l}.0968 \\
.0482\end{array}$ & $\begin{array}{l}.0449 \\
.0417 \\
.0388\end{array}$ & $\begin{array}{l}.0283 \\
.0260 \\
.0240\end{array}$ & $\begin{array}{l}.0228 \\
.0279 \\
.0254\end{array}$ & $\begin{array}{l}.0469 \\
.0428 \\
.0395\end{array}$ \\
\hline $\begin{array}{l}\text { Laplace }(2.0,1.0) \\
(3.00)\end{array}$ & $\begin{array}{l}.1166 \\
.0537\end{array}$ & $\begin{array}{l}.0493 \\
.0458 \\
.0427\end{array}$ & $\begin{array}{l}.0303 \\
.0281 \\
.0261\end{array}$ & $\begin{array}{l}.0324 \\
.0298 \\
.0271\end{array}$ & $\begin{array}{l}.0516 \\
.0475 \\
.0439\end{array}$ \\
\hline $\begin{array}{l}\operatorname{JTB}(4.0,1.0) \\
(0.78)\end{array}$ & $\begin{array}{l}.0742 \\
.0463\end{array}$ & $\begin{array}{l}.0468 \\
.0434 \\
.0404\end{array}$ & $\begin{array}{l}.0386 \\
.0361 \\
.0335\end{array}$ & $\begin{array}{l}.0436 \\
.0400 \\
.0367\end{array}$ & $\begin{array}{l}.0520 \\
.0479 \\
.0443\end{array}$ \\
\hline $\begin{array}{l}\mathrm{T}(16) \\
(0.50)\end{array}$ & $\begin{array}{l}.0658 \\
.0429\end{array}$ & $\begin{array}{l}.0440 \\
.0408 \\
.0377\end{array}$ & $\begin{array}{l}.0381 \\
.0350 \\
.0324\end{array}$ & $\begin{array}{l}.0430 \\
.0391 \\
.0355\end{array}$ & $\begin{array}{l}.0494 \\
.0454 \\
.0415\end{array}$ \\
\hline $\begin{array}{l}\operatorname{JTB}(1.25,0.5) \\
(0.24)\end{array}$ & $\begin{array}{l}.0587 \\
.0434\end{array}$ & $\begin{array}{l}.0457 \\
.0420 \\
.0391\end{array}$ & $\begin{array}{l}.0417 \\
.0387 \\
.0357\end{array}$ & $\begin{array}{l}.0483 \\
.0439 \\
.0401\end{array}$ & $\begin{array}{l}.0529 \\
.0483 \\
.0441\end{array}$ \\
\hline $\begin{array}{l}\mathrm{T}(32) \\
(0.21)\end{array}$ & $\begin{array}{l}.0583 \\
.0430\end{array}$ & $\begin{array}{l}.0447 \\
.0415 \\
.0382\end{array}$ & $\begin{array}{l}.0406 \\
.0375 \\
.0344\end{array}$ & $\begin{array}{l}.0462 \\
.0421 \\
.0382\end{array}$ & $\begin{array}{l}.0512 \\
.0468 \\
.0423\end{array}$ \\
\hline $\begin{array}{l}\operatorname{JTB}(2.0,0.5) \\
(-0.30)\end{array}$ & $\begin{array}{l}.0387 \\
.0338\end{array}$ & $\begin{array}{l}.0359 \\
.0325 \\
.0298\end{array}$ & $\begin{array}{l}.0350 \\
.0320 \\
.0291\end{array}$ & $\begin{array}{l}.0394 \\
.0350 \\
.0313\end{array}$ & $\begin{array}{l}.0410 \\
.0364 \\
.0325\end{array}$ \\
\hline
\end{tabular}

NOTE: Entries are the estimated proportion of samples rejected in 100,000 simulated samples for Zs, Zh, Z2, and Z6 test using $z_{\alpha},\left(z_{\alpha}+t_{\alpha, n-1}\right) / 2$, and $t_{\alpha, n-1}$ critical points (first, second, and third numbers in column Zs, Zh, Z2, and Z6) and chi-square and robust chi-square test (first and second) on the column $\chi^{2}, \chi_{r}^{2}$. 
Table 5. New Power Comparisons for Skewed Distribution Upper-Tailed

Rejection Region when $\sigma_{x}=k \sigma_{0}^{2}$, significance level $0.100, \mathbf{n}=40$

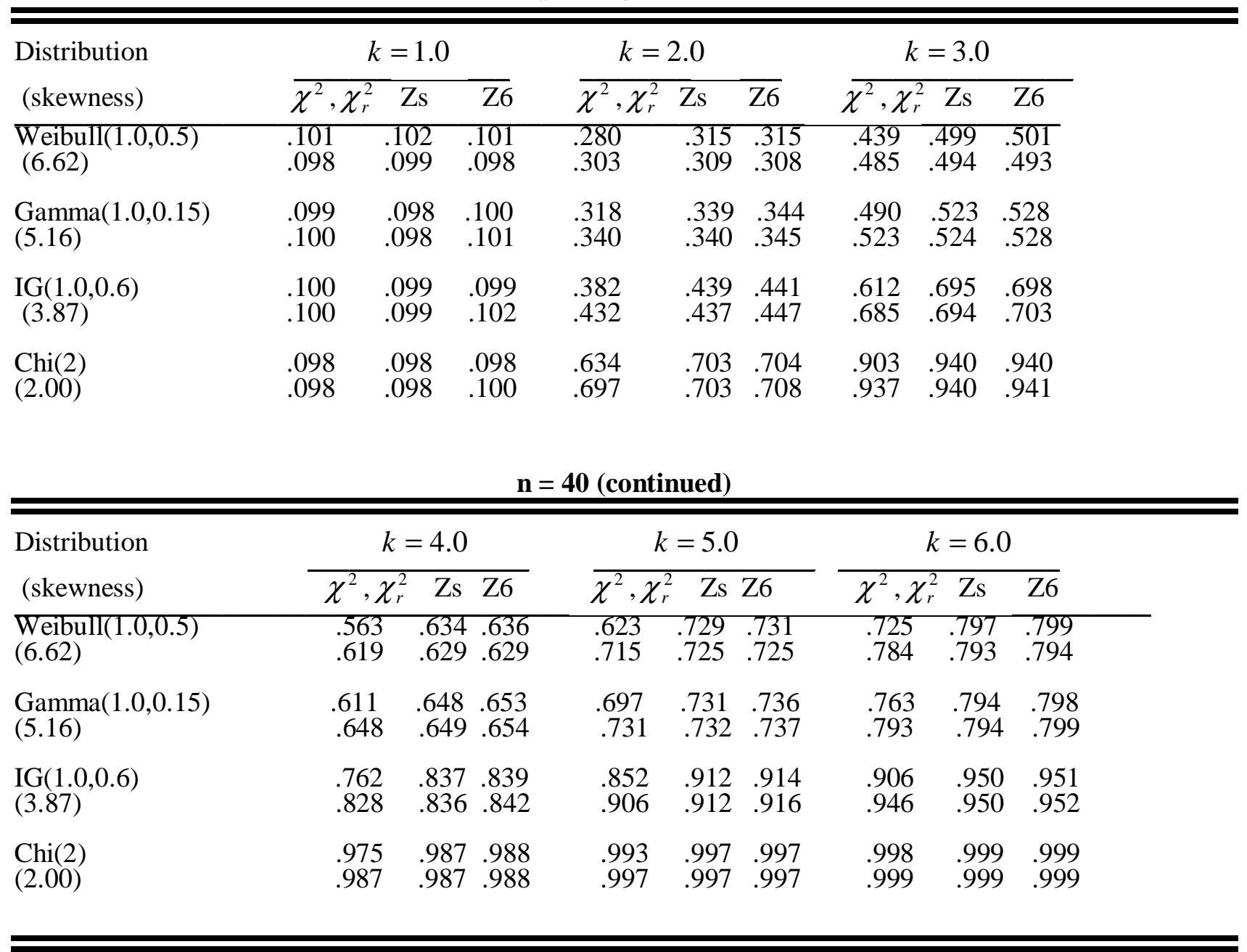

NOTE: Entries are the estimated proportion of samples rejected in 100,000 simulated samples for Zs and Z6 test using $z_{\alpha}$, and $\left(z_{\alpha}+t_{\alpha, n-1}\right) / 2$ critical points (first, and second numbers in column Zs and Z6) and chisquare and robust chi-square test (first and second) on the column $\chi^{2}, \chi_{r}^{2}$. 
Table 5 (continued). New Power Comparisons for Skewed Distribution Upper-Tailed Rejection Region when $\sigma_{x}=k \sigma_{0}^{2}$, significance level 0.100

$\mathrm{n}=\mathbf{2 0}$

\begin{tabular}{|c|c|c|c|c|c|c|c|c|c|c|}
\hline \multirow{2}{*}{$\begin{array}{l}\text { Distribution } \\
\text { (skewness) }\end{array}$} & \multicolumn{3}{|c|}{$k=1.0$} & \multicolumn{3}{|c|}{$k=2.0$} & \multicolumn{3}{|c|}{$k=3.0$} & \\
\hline & $\chi^{2}, \chi_{r}^{2}$ & Zs & $\bar{Z} 6$ & $\overline{\chi^{2}, \chi_{r}^{2}}$ & $\mathrm{Zs}$ & $\bar{Z} 6$ & $\overline{\chi^{2}}$, & $\chi_{r}^{2} \mathrm{Zs}$ & Z6 & \\
\hline $\begin{array}{l}\text { Weibull }(1.0,0.5) \\
(6.62)\end{array}$ & $\begin{array}{l}.100 \\
.101\end{array}$ & $\begin{array}{l}.101 \\
.100\end{array}$ & $\begin{array}{l}.102 \\
.101\end{array}$ & $\begin{array}{l}.231 \\
.248\end{array}$ & $\begin{array}{l}.253 \\
.251\end{array}$ & $\begin{array}{l}.255 \\
.254\end{array}$ & $\begin{array}{l}.343 \\
.374\end{array}$ & $\begin{array}{l}.382 \\
.380\end{array}$ & $\begin{array}{l}.385 \\
.384\end{array}$ & \\
\hline$\underset{(5.16)}{\operatorname{Gamma}}(1.0,0.15)$ & $\begin{array}{l}.100 \\
.100\end{array}$ & $\begin{array}{l}.101 \\
.101\end{array}$ & $\begin{array}{l}.100 \\
.100\end{array}$ & $\begin{array}{l}.254 \\
.263\end{array}$ & $\begin{array}{l}.266 \\
.267\end{array}$ & $\begin{array}{l}.265 \\
.266\end{array}$ & $\begin{array}{l}.375 \\
.389\end{array}$ & $\begin{array}{l}.394 \\
.395\end{array}$ & $\begin{array}{l}.393 \\
.394\end{array}$ & \\
\hline $\begin{array}{l}\mathrm{IG}(1.0,0.6) \\
(3.87)\end{array}$ & $\begin{array}{l}.099 \\
.098\end{array}$ & $\begin{array}{l}.098 \\
.098\end{array}$ & $\begin{array}{l}.101 \\
.100\end{array}$ & $\begin{array}{l}.295 \\
.325\end{array}$ & $\begin{array}{l}.331 \\
.332\end{array}$ & $\begin{array}{l}.340 \\
.337\end{array}$ & $\begin{array}{l}.459 \\
.511\end{array}$ & $\begin{array}{l}.519 \\
.520\end{array}$ & .531 & \\
\hline $\begin{array}{l}\text { Chi(2) } \\
(2.00)\end{array}$ & $\begin{array}{l}.099 \\
.099\end{array}$ & $\begin{array}{l}.102 \\
.100\end{array}$ & $\begin{array}{l}.102 \\
.098\end{array}$ & $\begin{array}{l}.469 \\
.514\end{array}$ & $\begin{array}{l}.525 \\
.521\end{array}$ & $\begin{array}{l}.527 \\
.519\end{array}$ & $\begin{array}{l}.729 \\
.777\end{array}$ & $\begin{array}{l}.786 \\
.783\end{array}$ & $\begin{array}{ll}5 & .788 \\
3 & .781\end{array}$ & \\
\hline \multicolumn{11}{|c|}{$\mathrm{n}=\mathbf{2 0}($ continued $)$} \\
\hline Distribution & \multicolumn{3}{|c|}{$k=4.0$} & \multicolumn{3}{|c|}{$k=5.0$} & \multicolumn{4}{|c|}{$k=6.0$} \\
\hline (skewness) & $\overline{\chi^{2}, \chi_{r}^{2}}$ & $\mathrm{Zs}$ & $\bar{Z} 6$ & $\overline{\chi^{2}, \chi_{r}^{2}}$ & Zs & $\bar{Z} 6$ & & $\overline{\chi^{2}, \chi_{r}^{2}}$ & $\mathrm{Zs}$ & Z6 \\
\hline $\begin{array}{l}\text { Weibull }(1 \overline{0,0.5)} \\
(6.62)\end{array}$ & $\begin{array}{l}.432 \\
.471\end{array}$ & $\begin{array}{l}.481 \\
.478\end{array}$ & $\begin{array}{l}.484 \\
.483\end{array}$ & $\begin{array}{l}.502 \\
.546\end{array}$ & $\begin{array}{l}.557 \\
.554\end{array}$ & $\begin{array}{l}.560 \\
.559\end{array}$ & & $\begin{array}{l}.570 \\
.616\end{array}$ & $\begin{array}{l}.627 \\
.625\end{array}$ & $\begin{array}{l}.631 \\
.629\end{array}$ \\
\hline$\underset{(5.16)}{\operatorname{Gamma}}(1.0,0.15)$ & $\begin{array}{l}.465 \\
.483\end{array}$ & $\begin{array}{l}.488 \\
.490\end{array}$ & $\begin{array}{l}.487 \\
.488\end{array}$ & $\begin{array}{l}.532 \\
.551\end{array}$ & $\begin{array}{l}.557 \\
.558\end{array}$ & $\begin{array}{l}.556 \\
.557\end{array}$ & & $\begin{array}{l}.585 \\
.606\end{array}$ & $\begin{array}{l}.611 \\
.612\end{array}$ & $\begin{array}{l}.610 \\
.610\end{array}$ \\
\hline $\begin{array}{l}\mathrm{IG}(1.0,0.6) \\
(3.87)\end{array}$ & $\begin{array}{l}.586 \\
.648\end{array}$ & $\begin{array}{l}.657 \\
.658\end{array}$ & $\begin{array}{l}.667 \\
.665\end{array}$ & $\begin{array}{l}.676 \\
.739\end{array}$ & $\begin{array}{l}.748 \\
.748\end{array}$ & $\begin{array}{l}.757 \\
.755\end{array}$ & & $\begin{array}{l}.742 \\
.802\end{array}$ & $\begin{array}{l}.811 \\
.811\end{array}$ & $\begin{array}{l}.818 \\
.816\end{array}$ \\
\hline $\begin{array}{l}\text { Chi(2) } \\
(2.00)\end{array}$ & $\begin{array}{l}.862 \\
.898\end{array}$ & $\begin{array}{l}.903 \\
.901\end{array}$ & $\begin{array}{l}.904 \\
.900\end{array}$ & $\begin{array}{l}.925 \\
.949\end{array}$ & $\begin{array}{l}.952 \\
.951\end{array}$ & $\begin{array}{l}.952 \\
.950\end{array}$ & & $\begin{array}{l}.959 \\
.974\end{array}$ & $\begin{array}{l}.975 \\
.975\end{array}$ & $\begin{array}{l}.976 \\
.975\end{array}$ \\
\hline
\end{tabular}

NOTE: Entries are the estimated proportion of samples rejected in 100,000 simulated samples for Zs and Z6 test using $z_{\alpha}$, and $\left(z_{\alpha}+t_{\alpha, n-1}\right) / 2$ critical points (first, and second numbers in column Zs and Z6) and chi-square and robust chi-square test (first and second) on the column $\chi^{2}, \chi_{r}^{2}$. 
Table 6. New Power Comparisons for Heavy-tail Upper-Tailed Rejection Region when $\sigma_{x}=k \sigma_{0}^{2}$ and significance level 0.100

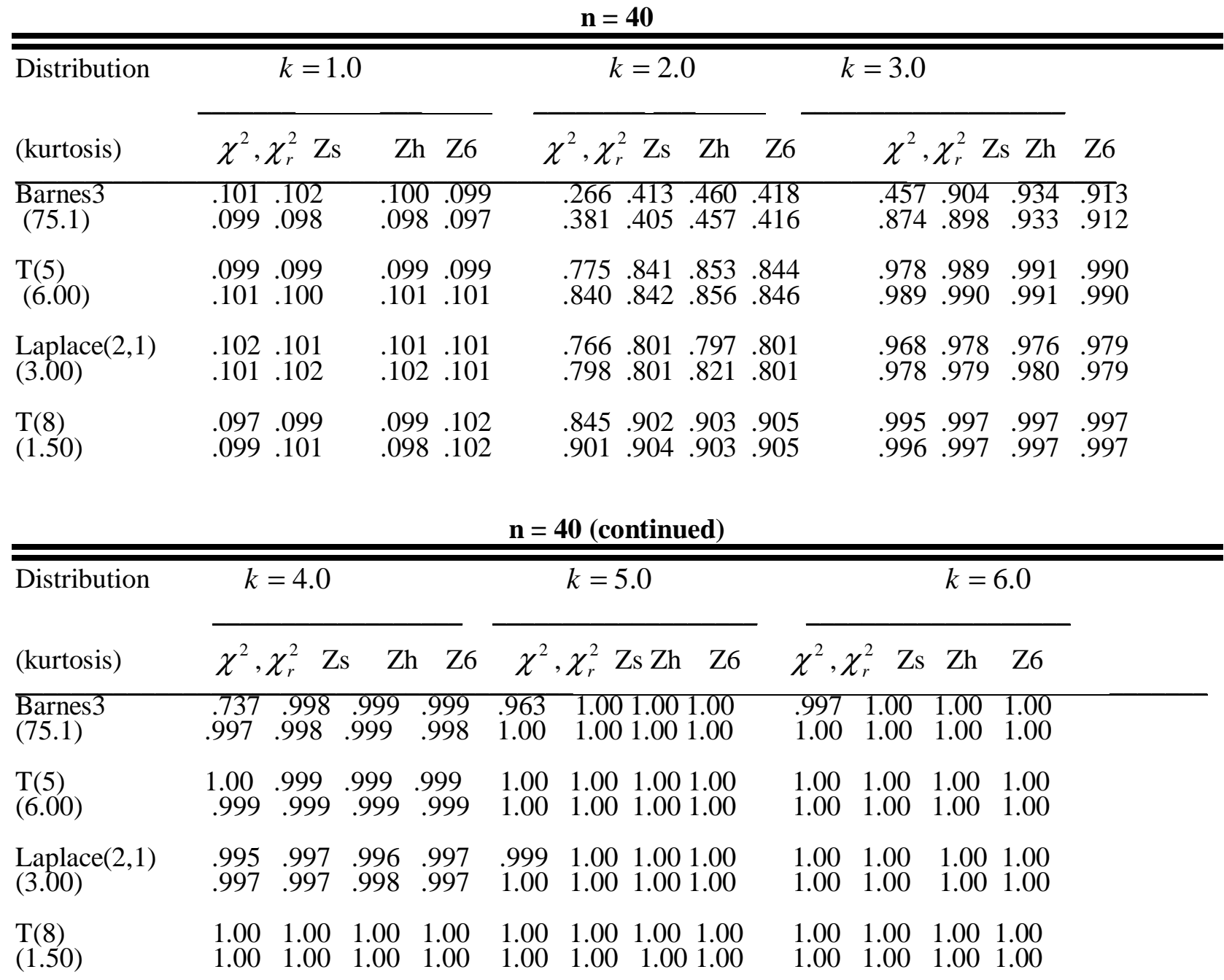

NOTE: Entries are the estimated proportion of samples rejected in 100,000 simulated samples for $\mathrm{Zs}, \mathrm{Zh}$, and Z6 test using $z_{\alpha}$, and $\left(z_{\alpha}+t_{\alpha, n-1}\right) / 2$ critical points (first, and second numbers in column Zs, Zh, and Z6) and chi-square and robust chi-square test (first and second) on the column $\chi^{2}, \chi_{r}^{2}$. 
206 RIGHT-TAILED TESTING OF VARIANCE FOR NON-NORMAL DISTRIBUTIONS

Table 6 (continued). New Power Comparisons for Heavy-tail Upper-Tailed Rejection Region when $\sigma_{x}=k \sigma_{0}^{2}$ and significance level 0.100

$$
\mathbf{n}=\mathbf{2 0}
$$

\begin{tabular}{|c|c|c|c|c|}
\hline \multirow{2}{*}{$\begin{array}{l}\text { Distribution } \\
\text { (kurtosis) }\end{array}$} & \multicolumn{2}{|l|}{$k=1.0$} & $k=2.0$ & $k=3.0$ \\
\hline & $\chi^{2}, \chi_{r}^{2} \mathrm{Zs} \mathrm{Zh}$ & Z6 & $\chi^{2}, \chi_{r}^{2} \mathrm{Zs} \quad \mathrm{Zh}$ & $\chi^{2}, \chi_{r}^{2} \mathrm{Zs} \quad \mathrm{Zh} \quad \mathrm{Z} 6$ \\
\hline $\begin{array}{l}\text { Barnes3 } \\
(75.1)\end{array}$ & $\begin{array}{llll}.100 & .099 & .099 & .1 \\
.101 & .101 & .099 & .0\end{array}$ & & $\begin{array}{lll}.217 & .302 & .323 \\
.290 & .306 & .331\end{array}$ & $\begin{array}{llll}.355 & .733 & .778 & .763 \\
.714 & .739 & .774 & .755\end{array}$ \\
\hline $\begin{array}{l}\mathrm{T}(5) \\
(6.00)\end{array}$ & $\begin{array}{llll}.102 & .102 & .101 & .1 \\
.100 & .102 & .101 & .1\end{array}$ & & $\begin{array}{lll}.584 & .646 & .662 \\
.637 & .648 & .662\end{array}$ & $\begin{array}{lllll}.868 .907 & .914 & .908 \\
.900 & .908 & .914 & .907\end{array}$ \\
\hline $\begin{array}{l}\text { Laplace }(2,1) \\
(3.00)\end{array}$ & $\begin{array}{llll}.099 & .099 & .091 & .0 \\
.099 & .02 & .01 & .0\end{array}$ & & $\begin{array}{lll}.565 & .601 & .613 \\
.560 & .608 & .604\end{array}$ & $\begin{array}{llll}.834 & .861 & .863 & .859 \\
.860 & .864 & .862 & .858\end{array}$ \\
\hline $\begin{array}{l}\mathrm{T}(8) \\
(1.50)\end{array}$ & $\begin{array}{llll}.102 & .100 & .100 & .1 \\
.101 & .102 & .098 & .0\end{array}$ & & $\begin{array}{lll}.691 & .714 & .715 \\
.714 & .716 & .714\end{array}$ & $\begin{array}{llll}.931 & .940 & .938 & .940 \\
.940 & .941 & .936 & .939\end{array}$ \\
\hline \multicolumn{5}{|c|}{$\mathbf{n}=\mathbf{2 0}($ continued $)$} \\
\hline Distribution & \multicolumn{2}{|l|}{$k=4.0$} & $k=5.0$ & $k=6.0$ \\
\hline (kurtosis) & $\chi^{2}, \chi_{r}^{2} \quad \mathrm{Zs} \mathrm{Zh}$ & $\mathrm{Z6}$ & $\chi^{2}, \chi_{r}^{2} \mathrm{Zs} \mathrm{Zh} \quad \mathrm{Z} 6$ & $\chi^{2}, \chi_{r}^{2} \quad \mathrm{Zs} \quad \mathrm{Zh}$ \\
\hline $\begin{array}{l}\text { Barnes3 } \\
(75.1)\end{array}$ & $\begin{array}{lll}.656 & .958 & .967 \\
.854 & .960 & .973\end{array}$ & $\begin{array}{l}.966 \\
.964\end{array}$ & $\begin{array}{llll}.899 & .993 & .996 & .995 \\
.992 & .993 & .996 & .994\end{array}$ & $\begin{array}{llll}.975 & .999 & .999 & .999 \\
.998 & .999 & .999 & .999\end{array}$ \\
\hline $\begin{array}{l}\mathrm{T}(5) \\
(6.00)\end{array}$ & $\begin{array}{lll}.960 & .973 & .976 \\
.972 & .974 & .976\end{array}$ & $\begin{array}{l}.974 \\
.975\end{array}$ & $\begin{array}{llll}.986 & .992 & .992 & .992 \\
.992 & .992 & .992 & .993\end{array}$ & $\begin{array}{llll}.995 & .997 & .997 & .997 \\
.997 & .997 & .997 & .997\end{array}$ \\
\hline $\begin{array}{l}\text { Laplace }(2,1) \\
(3.00)\end{array}$ & $\begin{array}{lll}.936 & .950 & .951 \\
.950 & .951 & .950\end{array}$ & $\begin{array}{l}.949 \\
.949\end{array}$ & $\begin{array}{llll}.973 & .980 & .978 & .980 \\
.980 & .981 & .986 & .980\end{array}$ & $\begin{array}{llll}.988 & .992 & .990 & .991 \\
.992 & .992 & .992 & .991\end{array}$ \\
\hline $\begin{array}{l}\mathrm{T}(8) \\
(1.50)\end{array}$ & $\begin{array}{lll}.984 & .986 & .984 \\
.986 & .986 & .984\end{array}$ & $\begin{array}{l}.986 \\
.986\end{array}$ & $\begin{array}{llll}.996 & .997 & .996 & .997 \\
.997 & .997 & .996 & .997\end{array}$ & $\begin{array}{llll}.999 & .999 & .999 & .999 \\
.999 & .999 & .999 & .999\end{array}$ \\
\hline
\end{tabular}

NOTE: Entries are the estimated proportion of samples rejected in 100,000 simulated samples for $\mathrm{Zs}$, Zh, and Z6 test using $z_{\alpha}$, and $\left(z_{\alpha}+t_{\alpha, n-1}\right) / 2$ critical points (first, and second numbers in column Zs, Zh, and Z6) and chi-square and robust chi-square test (first and second) on the column $\chi^{2}, \chi_{r}^{2}$. 
Table 7. Traditional Power Comparisons for Skewed Distribution Upper-Tailed Rejection Region when $\sigma_{x}=k \sigma_{0}^{2}$, significance level $0.100, \mathbf{n}=40$

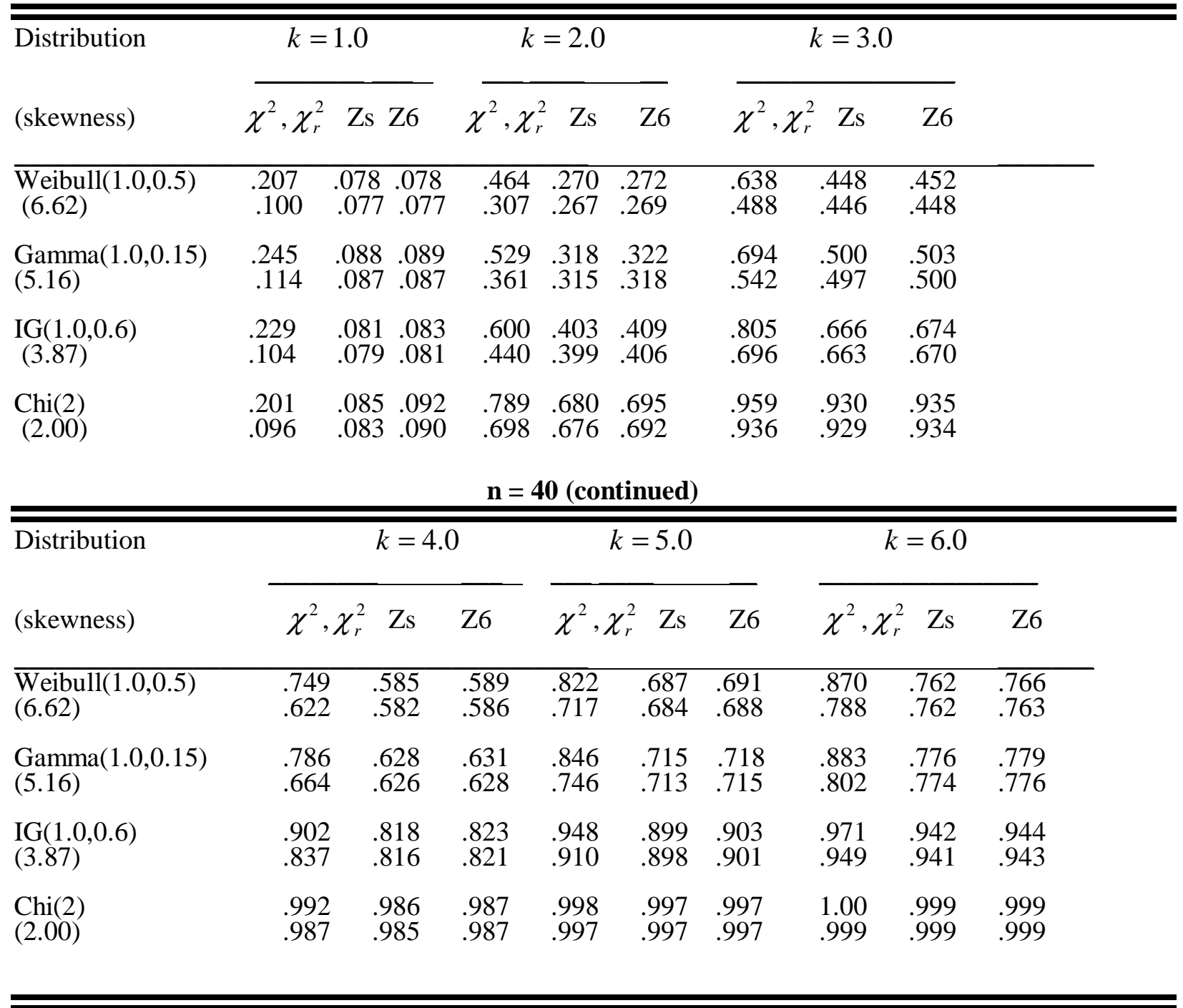

NOTE: Entries are the estimated proportion of samples rejected in 100,000 simulated samples for Zs and Z6 test using $z_{\alpha}$, and $\left(z_{\alpha}+t_{\alpha, n-1}\right) / 2$ critical points (first, and second numbers in column Zs and Z6) and chi-square and robust chi-square test (first and second) on the column $\chi^{2}, \chi_{r}^{2}$. 
208 RIGHT-TAILED TESTING OF VARIANCE FOR NON-NORMAL DISTRIBUTIONS

Table 7 (continued). Traditional Power Comparisons for Skewed Distribution Upper-Tailed

Rejection Region when $\sigma_{x}=k \sigma_{0}^{2}$, significance level $0.100, \mathbf{n}=20$

\begin{tabular}{|c|c|c|c|c|c|c|c|c|c|}
\hline \multirow{2}{*}{$\begin{array}{l}\text { Distribution } \\
\text { (skewness) }\end{array}$} & \multicolumn{3}{|c|}{$k=1.0$} & \multicolumn{3}{|c|}{$k=2.0$} & \multicolumn{3}{|c|}{$k=3.0$} \\
\hline & $\chi^{2}, \chi_{r}^{2}$ & $\mathrm{Zs}$ & Z6 & $\chi^{2}, \chi_{r}^{2}$ & $\mathrm{Zs}$ & Z6 & $\chi^{2}, \chi_{r}^{2}$ & $\mathrm{Zs}$ & Z6 \\
\hline $\begin{array}{l}\text { Weibull(1.0,0.5) } \\
(6.62)\end{array}$ & $\begin{array}{l}.173 \\
.097\end{array}$ & $\begin{array}{l}.080 \\
.078\end{array}$ & $\begin{array}{l}.080 \\
.078\end{array}$ & $\begin{array}{l}.354 \\
.245\end{array}$ & $\begin{array}{l}.218 \\
.214\end{array}$ & $\begin{array}{l}.220 \\
.215\end{array}$ & $\begin{array}{l}.482 \\
.364\end{array}$ & $\begin{array}{l}.336 \\
.332\end{array}$ & $\begin{array}{l}.340 \\
.334\end{array}$ \\
\hline $\begin{array}{l}\operatorname{Gamma}(1.0,0.15) \\
(5.16)\end{array}$ & $\begin{array}{l}.206 \\
.112\end{array}$ & $\begin{array}{l}.092 \\
.090\end{array}$ & $\begin{array}{l}.093 \\
.090\end{array}$ & $\begin{array}{l}.402 \\
.282\end{array}$ & $\begin{array}{l}.252 \\
.248\end{array}$ & $\begin{array}{l}.254 \\
.249\end{array}$ & $\begin{array}{l}.533 \\
.408\end{array}$ & $\begin{array}{l}.377 \\
.372\end{array}$ & $\begin{array}{l}.380 \\
.374\end{array}$ \\
\hline $\begin{array}{l}\mathrm{IG}(1.0,0.6) \\
(3.87)\end{array}$ & $\begin{array}{l}.197 \\
.106\end{array}$ & $\begin{array}{l}.089 \\
.086\end{array}$ & $\begin{array}{l}.091 \\
.088\end{array}$ & $\begin{array}{l}.457 \\
.335\end{array}$ & $\begin{array}{l}.310 \\
.304\end{array}$ & $\begin{array}{l}.317 \\
.310\end{array}$ & $\begin{array}{l}.628 \\
.519\end{array}$ & $\begin{array}{l}.495 \\
.489\end{array}$ & $\begin{array}{l}.504 \\
.497\end{array}$ \\
\hline $\begin{array}{l}\text { Chi(2) } \\
(2.00)\end{array}$ & $\begin{array}{l}.183 \\
.103\end{array}$ & $\begin{array}{l}.093 \\
.090\end{array}$ & $\begin{array}{l}.103 \\
.099\end{array}$ & $\begin{array}{l}.613 \\
.518\end{array}$ & $\begin{array}{l}.503 \\
.496\end{array}$ & $\begin{array}{l}.523 \\
.515\end{array}$ & $\begin{array}{l}.833 \\
.780\end{array}$ & $\begin{array}{l}.770 \\
.765\end{array}$ & $\begin{array}{l}.785 \\
.779\end{array}$ \\
\hline \multicolumn{10}{|c|}{$\mathrm{n}=\mathbf{2 0}($ continued $)$} \\
\hline Distribution & \multicolumn{3}{|c|}{$k=4.0$} & \multicolumn{3}{|c|}{$k=5.0$} & \multicolumn{3}{|c|}{$k=6.0$} \\
\hline (skewness) & $\chi^{2}, \chi_{r}^{2}$ & $\mathrm{Zs}$ & Z6 & $\chi^{2}, \chi_{r}^{2}$ & Zs & $\mathrm{Z} 6$ & $\chi^{2}, \chi_{r}^{2}$ & Zs & Z6 \\
\hline $\begin{array}{l}\text { Weibull(1.0,0.5) } \\
(6.62)\end{array}$ & $\begin{array}{l}.578 \\
.466\end{array}$ & $\begin{array}{l}.439 \\
.433\end{array}$ & $\begin{array}{l}.443 \\
.437\end{array}$ & $\begin{array}{l}.646 \\
.541\end{array}$ & $\begin{array}{l}.516 \\
.511\end{array}$ & $\begin{array}{l}.521 \\
.514\end{array}$ & $\begin{array}{l}.699 \\
.601\end{array}$ & $\begin{array}{l}.577 \\
.572\end{array}$ & $\begin{array}{l}.582 \\
.576\end{array}$ \\
\hline $\begin{array}{l}\operatorname{Gamma}(1.0,0.15) \\
(5.16)\end{array}$ & $\begin{array}{l}.615 \\
.502\end{array}$ & $\begin{array}{l}.471 \\
.466\end{array}$ & $\begin{array}{l}.473 \\
.467\end{array}$ & $\begin{array}{l}.677 \\
.574\end{array}$ & $\begin{array}{l}.546 \\
.541\end{array}$ & $\begin{array}{l}.548 \\
.542\end{array}$ & $\begin{array}{l}.722 \\
.627\end{array}$ & $\begin{array}{l}.601 \\
.597\end{array}$ & $\begin{array}{l}.604 \\
.598\end{array}$ \\
\hline $\begin{array}{l}\mathrm{IG}(1.0,0.6) \\
(3.87)\end{array}$ & $\begin{array}{l}.741 \\
.653\end{array}$ & $\begin{array}{l}.634 \\
.629\end{array}$ & $\begin{array}{l}.643 \\
.637\end{array}$ & $\begin{array}{l}.816 \\
.747\end{array}$ & $\begin{array}{l}.731 \\
.727\end{array}$ & $\begin{array}{l}.739 \\
.734\end{array}$ & $\begin{array}{l}.863 \\
.810\end{array}$ & $\begin{array}{l}.797 \\
.794\end{array}$ & $\begin{array}{l}.805 \\
.800\end{array}$ \\
\hline $\begin{array}{l}\text { Chi(2) } \\
(2.00)\end{array}$ & $\begin{array}{l}.924 \\
.898\end{array}$ & $\begin{array}{l}.893 \\
.890\end{array}$ & $\begin{array}{l}.901 \\
.897\end{array}$ & $\begin{array}{l}.964 \\
.951\end{array}$ & $\begin{array}{l}.949 \\
.947\end{array}$ & $\begin{array}{l}.953 \\
.951\end{array}$ & $\begin{array}{l}.982 \\
.974\end{array}$ & $\begin{array}{l}.973 \\
.972\end{array}$ & $\begin{array}{l}.976 \\
.975\end{array}$ \\
\hline
\end{tabular}

NOTE: Entries are the estimated proportion of samples rejected in 100,000 simulated samples for Zs and Z6 test using $z_{\alpha}$, and $\left(z_{\alpha}+t_{\alpha, n-1}\right) / 2$ critical points (first, and second numbers in column Zs and Z6) and chi-square and robust chi-square test (first and second) on the column $\chi^{2}, \chi_{r}^{2}$. 
Table 8. Traditional Power Comparisons for Heavy-tail Upper-Tailed Rejection Region when $\sigma_{x}=k \sigma_{0}^{2}$ and significance level $0.100, \mathbf{n}=40$

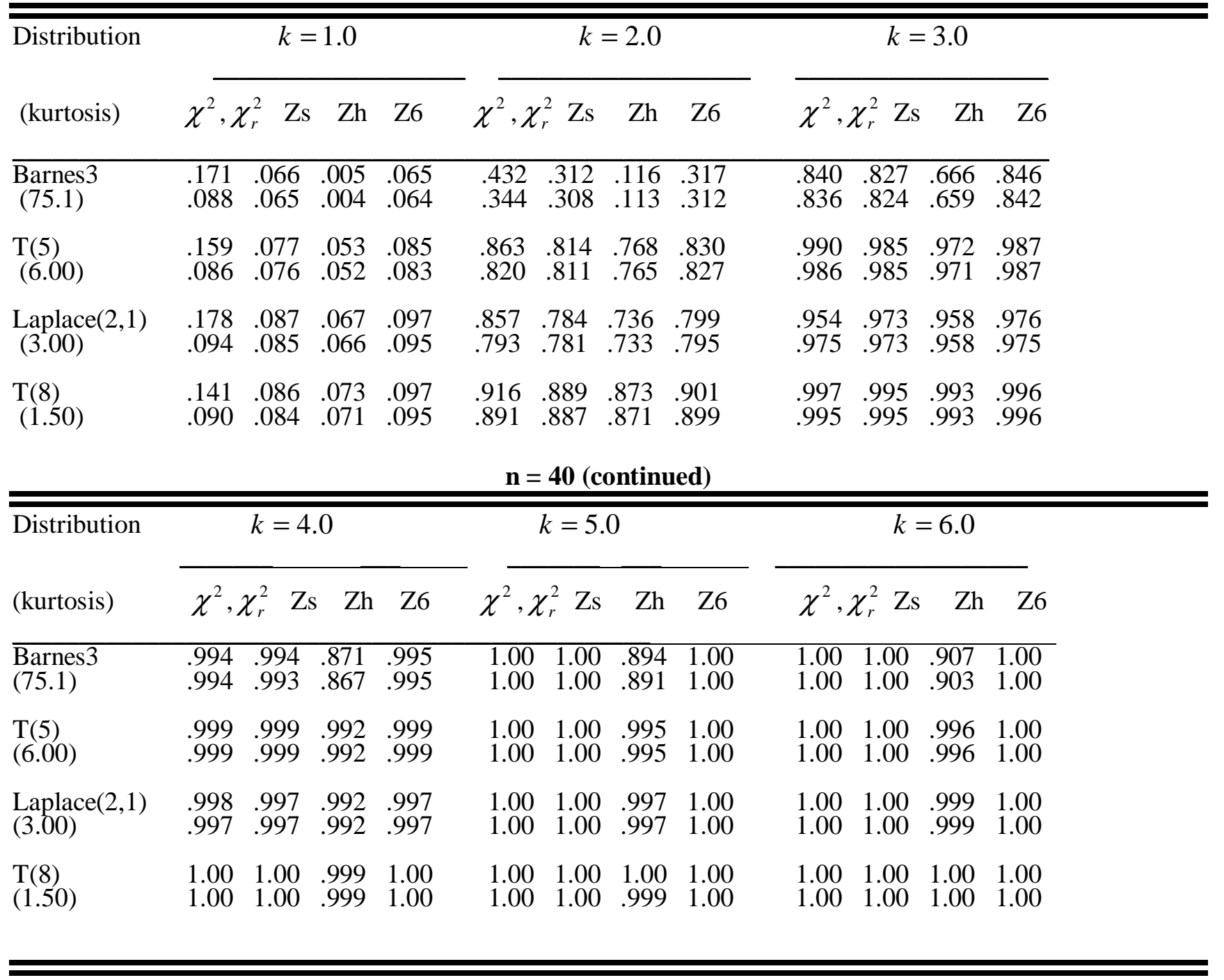

NOTE: Entries are the estimated proportion of samples rejected in 100,000 simulated samples for Zs, Zh, and Z6 test using $z_{\alpha}$, and $\left(z_{\alpha}+t_{\alpha, n-1}\right) / 2$ critical points (first, and second numbers in column Zs, Zh, and Z6) and chi-square and robust chi-square test (first and second) on the column $\chi^{2}, \chi_{r}^{2}$. 
210 RIGHT-TAILED TESTING OF VARIANCE FOR NON-NORMAL DISTRIBUTIONS

Table 8 (continued) Traditional Power Comparisons for Heavy-tail Upper-Tailed Rejection Region when $\sigma_{x}=k \sigma_{0}^{2}$ and significance level $0.100, \mathbf{n}=\mathbf{2 0}$

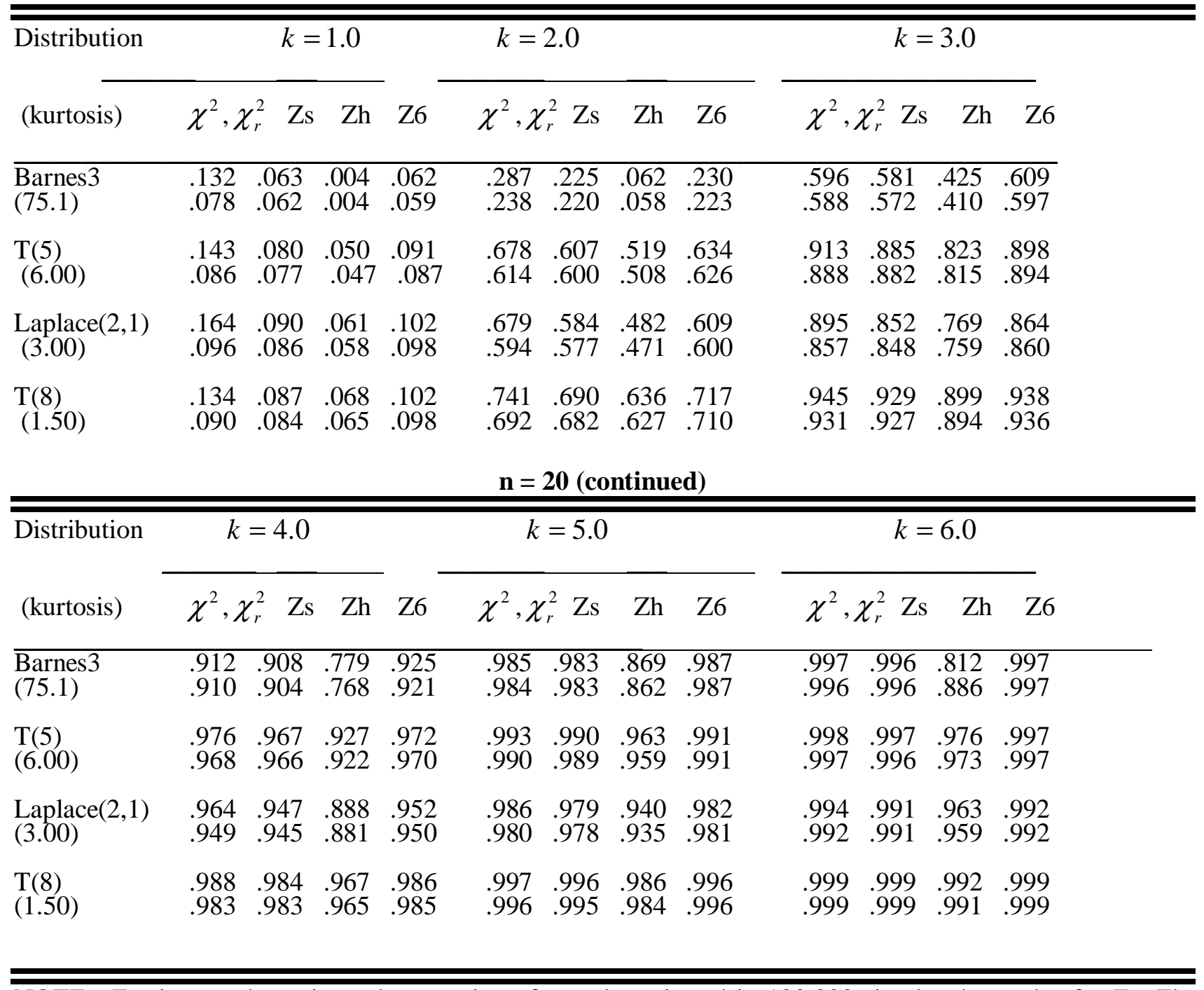

NOTE: Entries are the estimated proportion of samples rejected in 100,000 simulated samples for Zs, Zh, and Z6 test using $z_{\alpha}$, and $\left(z_{\alpha}+t_{\alpha, n-1}\right) / 2$ critical points (first, and second numbers in column Zs, Zh, and Z6) and chi-square and robust chi-square test (first and second) on the column $\chi^{2}, \chi_{r}^{2}$. 
Table 9. Comparisons of Type I Error Rates among Zs \& Z6 when n=30 Skewed Distributions

\begin{tabular}{|c|c|c|c|c|c|c|c|c|}
\hline \multirow{2}{*}{$\begin{array}{l}\text { Distribution } \\
\text { (skewness) }\end{array}$} & \multicolumn{2}{|c|}{$\alpha=0.10$} & \multicolumn{2}{|c|}{$\alpha=0.05$} & \multicolumn{2}{|c|}{$\alpha=0.02$} & \multicolumn{2}{|c|}{$\alpha=0.01$} \\
\hline & $\overline{\mathrm{Zs}}$ & $\mathrm{Z6}$ & $\mathrm{Zs}$ & $\mathrm{Z6}$ & $\overline{\mathrm{Zs}}$ & $\overline{Z 6}$ & $\overline{\mathrm{Zs}}$ & $\mathrm{Z6}$ \\
\hline $\begin{array}{l}\text { GG(1.0,0.1) } \\
(9.49)\end{array}$ & $\begin{array}{l}.0805 \\
.0792 \\
.0779\end{array}$ & $\begin{array}{l}.0792 \\
.0775 \\
.0759\end{array}$ & $\begin{array}{l}.0549 \\
.0534 \\
.0518\end{array}$ & $\begin{array}{l}.0454 \\
.0435 \\
.0416\end{array}$ & $\begin{array}{l}.0378 \\
.0361 \\
.0348\end{array}$ & $\begin{array}{l}.0224 \\
.0206 \\
.0189\end{array}$ & $\begin{array}{l}.0301 \\
.0286 \\
.0273\end{array}$ & $\begin{array}{l}.0138 \\
.0121 \\
.0108\end{array}$ \\
\hline $\begin{array}{l}\text { Weibull( }(1,0.5) \\
(6.62)\end{array}$ & $\begin{array}{l}.0802 \\
.0788 \\
.0775\end{array}$ & $\begin{array}{l}.0804 \\
.0786 \\
.0769\end{array}$ & $\begin{array}{l}.0517 \\
.0500 \\
.0484\end{array}$ & $\begin{array}{l}.0437 \\
.0416 \\
.0396\end{array}$ & $\begin{array}{l}.0305 \\
.0288 \\
.0273\end{array}$ & $\begin{array}{l}.0184 \\
.0168 \\
.0150\end{array}$ & $\begin{array}{l}.0234 \\
.0219 \\
.0204\end{array}$ & $\begin{array}{l}.0110 \\
.0095 \\
.0082\end{array}$ \\
\hline $\begin{array}{l}\operatorname{LN}(0,1) \\
(6.18)\end{array}$ & $\begin{array}{l}.0722 \\
.0706 \\
.0693\end{array}$ & $\begin{array}{l}.0729 \\
.0710 \\
.0693\end{array}$ & $\begin{array}{l}.0447 \\
.0431 \\
.0415\end{array}$ & $\begin{array}{l}.0381 \\
.0361 \\
.0342\end{array}$ & $\begin{array}{l}.0256 \\
.0243 \\
.0231\end{array}$ & $\begin{array}{l}.0158 \\
.0145 \\
.0132\end{array}$ & $\begin{array}{l}.0197 \\
.0181 \\
.0166\end{array}$ & $\begin{array}{l}.0091 \\
.0078 \\
.0069\end{array}$ \\
\hline $\begin{array}{l}\mathrm{IG}(1.0,0.25) \\
(6.00)\end{array}$ & $\begin{array}{l}.0833 \\
.0818 \\
.0802\end{array}$ & $\begin{array}{l}.0835 \\
.0816 \\
.0797\end{array}$ & $\begin{array}{l}.0512 \\
.0494 \\
.0478\end{array}$ & $\begin{array}{l}.0432 \\
.0409 \\
.0388\end{array}$ & $\begin{array}{l}.0324 \\
.0305 \\
.0290\end{array}$ & $\begin{array}{l}.0198 \\
.0181 \\
.0164\end{array}$ & $\begin{array}{l}.0231 \\
.0214 \\
.0198\end{array}$ & $\begin{array}{l}.0104 \\
.0091 \\
.0079\end{array}$ \\
\hline $\begin{array}{l}\operatorname{Gamma}(1, .15) \\
(5.16)\end{array}$ & $\begin{array}{l}.0877 \\
.0856 \\
.0837\end{array}$ & $\begin{array}{l}.0890 \\
.0863 \\
.0840\end{array}$ & $\begin{array}{l}.0538 \\
.0517 \\
.0499\end{array}$ & $\begin{array}{l}.0472 \\
.0448 \\
.0427\end{array}$ & $\begin{array}{l}.0298 \\
.0280 \\
.0265\end{array}$ & $\begin{array}{l}.0200 \\
.0179 \\
.0161\end{array}$ & $\begin{array}{l}.0212 \\
.0196 \\
.0178\end{array}$ & $\begin{array}{l}.0110 \\
.0098 \\
.0085\end{array}$ \\
\hline $\begin{array}{l}\mathrm{IG}(1.0,0.5) \\
(4.24)\end{array}$ & $\begin{array}{l}.0828 \\
.0811 \\
.0803\end{array}$ & $\begin{array}{l}.0864 \\
.0833 \\
.0814\end{array}$ & $\begin{array}{l}.0503 \\
.0481 \\
.0464\end{array}$ & $\begin{array}{l}.0447 \\
.0421 \\
.0397\end{array}$ & $\begin{array}{l}.0264 \\
.0245 \\
.0227\end{array}$ & $\begin{array}{l}.0175 \\
.0158 \\
.0141\end{array}$ & $\begin{array}{l}.0182 \\
.0165 \\
.0149\end{array}$ & $\begin{array}{l}.0101 \\
.0090 \\
.0080\end{array}$ \\
\hline $\begin{array}{l}\text { Chi(1) } \\
(2.83)\end{array}$ & $\begin{array}{l}.0886 \\
.0864 \\
.0843\end{array}$ & $\begin{array}{l}.0942 \\
.0915 \\
.0890\end{array}$ & $\begin{array}{l}.0490 \\
.0468 \\
.0448\end{array}$ & $\begin{array}{l}.0477 \\
.0453 \\
.0430\end{array}$ & $\begin{array}{l}.0241 \\
.0221 \\
.0203\end{array}$ & $\begin{array}{l}.0214 \\
.0193 \\
.0176\end{array}$ & $\begin{array}{l}.0155 \\
.0138 \\
.0126\end{array}$ & $\begin{array}{l}.0128 \\
.0115 \\
.0102\end{array}$ \\
\hline $\begin{array}{l}\operatorname{Exp}(1.0) \\
(2.00)\end{array}$ & $\begin{array}{l}.0880 \\
.0857 \\
.0835\end{array}$ & $\begin{array}{l}.0970 \\
.0944 \\
.0918\end{array}$ & $\begin{array}{l}.0463 \\
.0441 \\
.0420\end{array}$ & $\begin{array}{l}.0486 \\
.0459 \\
.0437\end{array}$ & $\begin{array}{l}.0229 \\
.0210 \\
.0195\end{array}$ & $\begin{array}{l}.0226 \\
.0206 \\
.0189\end{array}$ & $\begin{array}{l}.0145 \\
.0129 \\
.0115\end{array}$ & $\begin{array}{l}.0141 \\
.0125 \\
.0110\end{array}$ \\
\hline $\begin{array}{l}\text { Chi(2) } \\
(2.00)\end{array}$ & $\begin{array}{l}.0894 \\
.0872 \\
.0848\end{array}$ & $\begin{array}{l}.0978 \\
.0951 \\
.0930\end{array}$ & $\begin{array}{l}.0472 \\
.0450 \\
.0428\end{array}$ & $\begin{array}{l}.0494 \\
.0468 \\
.0446\end{array}$ & $\begin{array}{l}.0233 \\
.0214 \\
.0196\end{array}$ & $\begin{array}{l}.0230 \\
.0210 \\
.0191\end{array}$ & $\begin{array}{l}.0146 \\
.0128 \\
.0116\end{array}$ & $\begin{array}{l}.0140 \\
.0123 \\
.0111\end{array}$ \\
\hline $\begin{array}{l}\text { Barnes2 } \\
(1.75)\end{array}$ & $\begin{array}{l}.0933 \\
.0912 \\
.0891\end{array}$ & $\begin{array}{l}.1048 \\
.1022 \\
.0995\end{array}$ & $\begin{array}{l}.0518 \\
.0497 \\
.0474\end{array}$ & $\begin{array}{l}.0570 \\
.0546 \\
.0520\end{array}$ & $\begin{array}{l}.0265 \\
.0245 \\
.0225\end{array}$ & $\begin{array}{l}.0284 \\
.0262 \\
.0240\end{array}$ & $\begin{array}{l}.0169 \\
.0151 \\
.0136\end{array}$ & $\begin{array}{l}.0181 \\
.0161 \\
.0145\end{array}$ \\
\hline $\begin{array}{l}\mathrm{IG}(1.0,25.0) \\
(0.60)\end{array}$ & $\begin{array}{l}.0865 \\
.0841 \\
.0816\end{array}$ & $\begin{array}{l}.1021 \\
.0990 \\
.0963\end{array}$ & $\begin{array}{l}.0441 \\
.0418 \\
.0398\end{array}$ & $\begin{array}{l}.0505 \\
.0478 \\
.0452\end{array}$ & $\begin{array}{l}.0204 \\
.0185 \\
.0168\end{array}$ & $\begin{array}{l}.0216 \\
.0198 \\
.0178\end{array}$ & $\begin{array}{l}.0109 \\
.0098 \\
.0087\end{array}$ & $\begin{array}{l}.0112 \\
.0094 \\
.0081\end{array}$ \\
\hline $\begin{array}{l}\text { Chi(24) } \\
(0.58)\end{array}$ & $\begin{array}{l}.0868 \\
.0845 \\
.0821\end{array}$ & $\begin{array}{l}.1017 \\
.0990 \\
.0963\end{array}$ & $\begin{array}{l}.0420 \\
.0399 \\
.0377\end{array}$ & $\begin{array}{l}.0483 \\
.0456 \\
.0433\end{array}$ & $\begin{array}{l}.0187 \\
.0169 \\
.0153\end{array}$ & $\begin{array}{l}.0202 \\
.0180 \\
.0163\end{array}$ & $\begin{array}{l}.0110 \\
.0097 \\
.0086\end{array}$ & $\begin{array}{l}.0109 \\
.0094 \\
.0079\end{array}$ \\
\hline
\end{tabular}

NOTE: Entries are the estimated proportion of samples rejected in 100,000 simulated samples for Zs and Z6 test using $z_{\alpha},\left(z_{\alpha}+t_{\alpha, n-1}\right) / 2$, and $t_{\alpha, n-1}$ critical points (first, second, and third numbers in column Zs and Z6). 
Table 9 (continued). Comparisons of Type I Error Rates among Zs \& Z6 when $\mathrm{n}=30$ Heavy-tailed Distributions

\begin{tabular}{|c|c|c|c|c|c|c|c|c|}
\hline \multirow{2}{*}{$\begin{array}{l}\text { Distribution } \\
\text { (skewness) }\end{array}$} & \multicolumn{2}{|c|}{$\alpha=0.10$} & \multicolumn{2}{|c|}{$\alpha=0.05$} & \multicolumn{2}{|c|}{$\alpha=0.02$} & \multicolumn{2}{|c|}{$\alpha=0.01$} \\
\hline & $\mathrm{Zs}$ & $\mathrm{Z6}$ & $\mathrm{Zs}$ & $\mathrm{Z6}$ & $\overline{Z s}$ & $\overline{Z 6}$ & $\overline{Z s}$ & $\overline{Z 6}$ \\
\hline $\begin{array}{l}\text { Barnes3 } \\
(75.1)\end{array}$ & $\begin{array}{l}.0644 \\
.0630 \\
.0615\end{array}$ & $\begin{array}{l}.0631 \\
.0613 \\
.0596\end{array}$ & $\begin{array}{l}.0390 \\
.0379 \\
.0367\end{array}$ & $\begin{array}{l}.0303 \\
.0286 \\
.0270\end{array}$ & $\begin{array}{l}.0261 \\
.0249 \\
.0238\end{array}$ & $\begin{array}{l}.0135 \\
.0121 \\
.0108\end{array}$ & $\begin{array}{l}.0196 \\
.0186 \\
.0175\end{array}$ & $\begin{array}{l}.0067 \\
.0056 \\
.0047\end{array}$ \\
\hline $\begin{array}{l}\mathrm{T}(5) \\
(6.00)\end{array}$ & $\begin{array}{l}.0795 \\
.0775 \\
.0754\end{array}$ & $\begin{array}{l}.0887 \\
.0861 \\
.0835\end{array}$ & $\begin{array}{l}.0385 \\
.0365 \\
.0347\end{array}$ & $\begin{array}{l}.0388 \\
.0365 \\
.0342\end{array}$ & $\begin{array}{l}.0170 \\
.0157 \\
.0143\end{array}$ & $\begin{array}{l}.0144 \\
.0128 \\
.0113\end{array}$ & $\begin{array}{l}.0103 \\
.0088 \\
.0077\end{array}$ & $\begin{array}{l}.0075 \\
.0065 \\
.0054\end{array}$ \\
\hline $\begin{array}{l}\text { Barnes1 } \\
(6.00)\end{array}$ & $\begin{array}{l}.1014 \\
.0988 \\
.0965\end{array}$ & $\begin{array}{l}.1096 \\
.1066 \\
.1035\end{array}$ & $\begin{array}{l}.0517 \\
.0490 \\
.0468\end{array}$ & $\begin{array}{l}.0507 \\
.0477 \\
.0448\end{array}$ & $\begin{array}{l}.0234 \\
.0215 \\
.0197\end{array}$ & $\begin{array}{l}.0191 \\
.0169 \\
.0151\end{array}$ & $\begin{array}{l}.0146 \\
.0128 \\
.0113\end{array}$ & $\begin{array}{l}.0107 \\
.0091 \\
.0076\end{array}$ \\
\hline $\begin{array}{l}\mathrm{T}(6) \\
(3.00)\end{array}$ & $\begin{array}{l}.0823 \\
.0799 \\
.0777\end{array}$ & $\begin{array}{l}.0932 \\
.0903 \\
.0875\end{array}$ & $\begin{array}{l}.0407 \\
.0385 \\
.0365\end{array}$ & $\begin{array}{l}.0431 \\
.0404 \\
.0381\end{array}$ & $\begin{array}{l}.0180 \\
.0163 \\
.0148\end{array}$ & $\begin{array}{l}.0170 \\
.0151 \\
.0134\end{array}$ & $\begin{array}{l}.0102 \\
.0089 \\
.0078\end{array}$ & $\begin{array}{l}.0088 \\
.0075 \\
.0062\end{array}$ \\
\hline $\begin{array}{l}\text { Laplace }(2,1) \\
(3.00)\end{array}$ & $\begin{array}{l}.0879 \\
.0857 \\
.0836\end{array}$ & $\begin{array}{l}.0911 \\
.0893 \\
.0879\end{array}$ & $\begin{array}{l}.0444 \\
.0423 \\
.0401\end{array}$ & $\begin{array}{l}.0474 \\
.0448 \\
.0422\end{array}$ & $\begin{array}{l}.0203 \\
.0186 \\
.0170\end{array}$ & $\begin{array}{l}.0199 \\
.0179 \\
.0161\end{array}$ & $\begin{array}{l}.0124 \\
.0108 \\
.0096\end{array}$ & $\begin{array}{l}.0113 \\
.0098 \\
.0084\end{array}$ \\
\hline $\begin{array}{l}\operatorname{JTB}(4.0,1.0) \\
(0.78)\end{array}$ & $\begin{array}{l}.0894 \\
.0872 \\
.0851\end{array}$ & $\begin{array}{l}.1045 \\
.1008 \\
.0979\end{array}$ & $\begin{array}{l}.0455 \\
.0431 \\
.0409\end{array}$ & $\begin{array}{l}.0516 \\
.0490 \\
.0461\end{array}$ & $\begin{array}{l}.0203 \\
.0185 \\
.0168\end{array}$ & $\begin{array}{l}.0212 \\
.0193 \\
.0172\end{array}$ & $\begin{array}{l}.0117 \\
.0103 \\
.0092\end{array}$ & $\begin{array}{l}.0114 \\
.0099 \\
.0083\end{array}$ \\
\hline $\mathrm{T}(16)$ & .0882 & .1035 & .0441 & .0504 & .0195 & .0205 & .0112 & .0107 \\
\hline$(0.50)$ & $\begin{array}{l}.0859 \\
.0836\end{array}$ & $\begin{array}{l}.1007 \\
.0977\end{array}$ & $\begin{array}{l}.0417 \\
.0397\end{array}$ & $\begin{array}{l}.0476 \\
.0450\end{array}$ & $\begin{array}{l}.0179 \\
.0160\end{array}$ & $\begin{array}{l}.0184 \\
.0165\end{array}$ & $\begin{array}{l}.0099 \\
.0087\end{array}$ & $\begin{array}{l}.0092 \\
.0078\end{array}$ \\
\hline $\begin{array}{l}\operatorname{JTB}(1.25,0.5) \\
(0.24)\end{array}$ & $\begin{array}{l}.0895 \\
.0856 \\
.0827\end{array}$ & $\begin{array}{l}.1059 \\
.1017 \\
.0988\end{array}$ & $\begin{array}{l}.0441 \\
.0419 \\
.0398\end{array}$ & $\begin{array}{l}.0518 \\
.0486 \\
.0459\end{array}$ & $\begin{array}{l}.0190 \\
.0172 \\
.0156\end{array}$ & $\begin{array}{l}.0203 \\
.0183 \\
.0163\end{array}$ & $\begin{array}{l}.0116 \\
.0100 \\
.0087\end{array}$ & $\begin{array}{l}.0114 \\
.0098 \\
.0081\end{array}$ \\
\hline $\begin{array}{l}\mathrm{T}(32) \\
(0.21)\end{array}$ & $\begin{array}{l}.0884 \\
.0859 \\
.0834\end{array}$ & $\begin{array}{l}.1049 \\
.1019 \\
.0992\end{array}$ & $\begin{array}{l}.0436 \\
.0415 \\
.0391\end{array}$ & $\begin{array}{l}.0501 \\
.0476 \\
.0452\end{array}$ & $\begin{array}{l}.0186 \\
.0169 \\
.0151\end{array}$ & $\begin{array}{l}.0196 \\
.0175 \\
.0157\end{array}$ & $\begin{array}{l}.0107 \\
.0093 \\
.0083\end{array}$ & $\begin{array}{l}.0103 \\
.0086 \\
.0074\end{array}$ \\
\hline $\begin{array}{l}\mathrm{JTB}(2.0,0.5) \\
(-0.30)\end{array}$ & $\begin{array}{l}.0769 \\
.0743 \\
.0705\end{array}$ & $\begin{array}{l}.0943 \\
.0903 \\
.0868\end{array}$ & $\begin{array}{l}.0350 \\
.0327 \\
.0306\end{array}$ & $\begin{array}{l}.0408 \\
.0382 \\
.0355\end{array}$ & $\begin{array}{l}.0131 \\
.0117 \\
.0105\end{array}$ & $\begin{array}{l}.0131 \\
.0113 \\
.0098\end{array}$ & $\begin{array}{l}.0067 \\
.0059 \\
.0049\end{array}$ & $\begin{array}{l}.0055 \\
.0044 \\
.0034\end{array}$ \\
\hline
\end{tabular}

NOTE: Entries are the estimated proportion of samples rejected in 100,000 simulated samples for Zs and Z6 test using $z_{\alpha},\left(z_{\alpha}+t_{\alpha, n-1}\right) / 2$, and $t_{\alpha, n-1}$ critical points (first, second, and third numbers in column Zs and Z6). 


\section{Conclusion}

This study proposed a new right-tailed test of the variance of non-normal distributions. The test is adapted from Hall's inverse Edgeworth expansion for variance (1992) with the purpose to find a new test with fewer restrictions from assumptions and no need for the knowledge of the distribution type. To this end, the study compared Type I error rates and power of previously known tests to its own.

Of the previous tests and six new tests examined by the study, Z6 had the best performance for right-tailed tests. The $\mathrm{Z} 6$ test outperforms the $\chi^{2}$ test by far while performing much better than the $\chi_{r}^{2}$ test on skewed distributions and better with heavy-tailed distributions. The Z6 test does not need the original assumptions for the $\mathrm{Zs}$ test that the coefficient of skewness of the parent distribution is greater than $\sqrt{2}$ or that the distribution is skewed.

Additionally, the Z6 test performs better overall than the Zs test since Zs performs poorly with smaller alpha levels. Test Z6, unlike Zh, does not need the original assumptions that the population coefficient of skewness is zero in the heavy-tailed distribution or that the distribution is heavy-tailed. Also, the Z6 test performs better for skewed distributions than the $\mathrm{Zh}$ test, which has low power at lower alphas. Finally, when considering the Type I error rates, both distribution types, and power, the Z6 test is the best in performance overall. The Z6 test can be used for both types of distributions with good power performance and superior Type I error rates. Therefore, the $\mathrm{Z} 6$ test is a good choice for right-tailed tests of variance with non-normal distributions

\section{References}

Efron, B., \& Tibshirani, R. J. (1993). An Introduction to the bootstrap. New York: Chapman \& Hall.

Kendall, S. M. (1994). Distribution theory. New York: Oxford University Press Inc.
Lee, S. J., \& Sa, P. (1998). Testing the variance of skewed distributions. Communications in Statistics: Simulation and Computation, 27(3), 807-822.

Lee, S. J., \& Sa, P. (1996). Testing the variance of symmetric heavy-tailed distributions. Journal of Statistical Computation and Simulation, 56, 39-52.

Bickel, P. J., \& Doksum, K. A. (1977). Mathematical statistics -Basic idea and selected topics. San Francisco: Holden-Day.

Hall, P. (1983). Inverting an edgeworth expansion. The Annals of Statistics, 11, 2, 569576.

Kendall, S. M., \& Stuart, A. (1969). The advanced theory of statistics-distribution theory, Vol.I, $4^{\text {th }}$ Edition, Griffith Inc.

Hall, P. (1992). The bootstrap and edgeworth. New York: Springer-Verlag.

Evans, M., Hastings, N., \& Peacock, B. (2000). Statistical distributions, $3^{\text {rd }}$ Edition, New York: John Wiley \& Sons, Inc..

Chhikara, R. S., \& Folks, J. L. (1989). The inverse gaussian distribution-theory, methodology and applications. Marcel Dekker, Inc.

Fleishman, A. I. (1978). A method of simulating non-normal distributions, Psychometrica, 43, 521-531

Johnson, M. E., Tietjen, G. L., \& Beckman, R. J. (1980). A new family of probability distributions with applications to monte carlo studies. Journal of the American Statistical Association, 75, 370, 276-279

Long, M., \& Sa, P., The Simulation Results for Right-tailed Testing of Variance for Non-Normal Distributions, Technical Report, \#030503, Department of Mathematics and Statistics, University of North Florida, http://www.unf.edu/coas/math-

stat/CRCS/CRTechRep.htm, 2003. 